\title{
Neolithic Inhabitants of Khor Shambat 1, Sudan
}

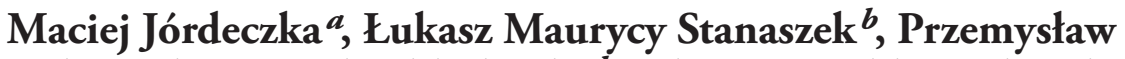 \\ Bobrowski $^{c}$, Marek Chłodnicki ${ }^{d}$ and Iwona Sobkowiak-Tabaka ${ }^{e}$
}

Ever since Arkell launched research excavation in Shaheinab, many Neolithic sites of varying
scientific value have been discovered in Central Sudan. These discoveries included both sites and
cemeteries that shed some light not only on the economy, but also on the social structure and beliefs
of ancient populations. Sites such as Kadero, el-Geili, el-Ghaba, Shaqadud and el-Kadada have
become benchmarks for describing and understanding the Neolithic in Central Sudan. In recent
years, another exceptional site has joined this group - Khor Shambat 1 (KSH 1). Research here
has revealed a Mesolithic and Neolithic site. The investigation of about I\% of the area of KSH 1
uncovered 66 graves, including about 30 Neolithic ones. Yet this relatively low number of occur-
rences included burials which shed a very interesting light on the local communities. Especially
noteworthy is the extraordinary approach to burials of children and in particular the youngest
members of the community, newborns and fetuses; their graves are by far the richest. Some of
them were buried in ceramic vessels and equipped with numerous gifts. The most distinctive grave
in terms of the wealth of its burial goods is that of a female who died in advanced pregnancy.
The chronology of the Neolithic site and cemetery, determined on the basis of a series of radio-
carbon dates and ceramics analyses, is generally set in the second half of the sth millennium BC.

KEY-WORDS: Khor Shambat, Central Sudan, Omdurman, Neolithic, Cemetery, Graves

a Institute of Archaeology and Ethnology, Polish Academy of Sciences, Rubież Street 46, 6I-6I2 Poznan, Poland; e-mail: maciej.jordeczka@iaepan.poznan.pl; ORCID: 0000-0002-5026-4528

$b$ Anthropological Laboratory, State Archaeological Museum, Długa Street 52 (Arsenal), o0-24I Warsaw, Poland; e-mail: maurycystanaszek@wp.pl; ORCID: 0000-0003-2743-2922

c Institute of Archaeology and Ethnology, Polish Academy of Sciences, Rubież Street 46, 6I-6I2 Poznan, Poland; e-mail: przemyslawbobrowski@iaepan.poznan.pl; ORCID: 0000-0002-7537-1856

$d$ Archaeological Museum in Poznan, Wodna Street 27, 6I-78I Poznan, Poland; e-mail: mchlod@man. poznan.pl; ORCID: 0000-0002-1728-464X

e Faculty of Archaeology Adam Mickiewicz University in Poznan, Uniwersytetu Poznańskiego Street 7 , 6I-6I4 Poznan, Poland; e-mail: iwosob@amu.edu.pl; ORCID: 0000-0001-5913-1177 
I36 M. Jórdeczka, E. M. Stanaszek, P. Bobrowski, M. Chtodnicki and I. Sobkowiak-Tabaka

\section{INTRODUCTION}

The KSH 1 site, situated in Omdurman on the west bank of the Nile (Fig. I) has been known for only a few years. ${ }^{1}$ The first survey excavation was conducted here in December 20I2, with a focus on the southern part of the site. The work allowed researchers to assess its potential, especially with regards to Neolithic settlement and the associated cemetery (Bobrowski et al., 20I6). Research work was reinstated in 2016 within the scope of the National Science Centre Poland project ${ }^{2}$ under Grant number 2015/17/D/HS3/01492.

The research significantly enhanced our knowledge about KSH 1 and brought about the discovery of a sophisticated stratigraphy which extends over 3500 years and goes back as far as the Early Mesolithic. To date, a surface area of around $150 \mathrm{~m}^{2}$ has been examined.

\section{KHOR SHAMBAT 1 - THE SITE}

Khor Shambat ${ }^{3} 1$ is located on the $384 \mathrm{~m}$ a.s.l. contour line (around $5 \mathrm{~m}$ above the current maximum overflow level of the river), covers an area of approximately 1.5 ha (Fig. 2) and is bordered to the south and north by two small gorges. The mound-like site is located on a small hill made of limestone; on it lies a layer of heavily eroded iron mudstone, which makes up the natural substrate under the site. This layer is covered in turn by layers made up predominantly of silty sands, probably of aeolian origin, the thickness of which reaches over $1.50 \mathrm{~m}$ in the central part of the site. These layers revealed a stratigraphic sequence and consist of Mesolithic (approx. 1.50-0.90 m below the recent surface) and Neolithic (above) cultural layers. All this is covered by a contemporary gravel midden 0.10 to $0.30 \mathrm{~m}$ thick, which also contains mixed prehistoric material. Unfortunately, a significant part of the site, mainly the Neolithic deposit, was destroyed by Meroitic and Post-Meroitic disturbances (cemeteries), as well as animal activity. Nearly half of the area of the site has also been destroyed by modern economic and residential activity.

1 The site was discovered in 20I2, during the intervention of the Sudanese National Corporation for Antiquities and Museums (NCAM), conducted by Mahmoud Suleiman al Bashir. The first rescue excavation was conducted by a team from the Institute of Archaeology and Ethnology of the Polish Academy of Sciences. The project was conducted on behalf of the Polish Centre of Mediterranean Archaeology of the University of Warsaw.

2 The project was entitled: A new perspective on prehistoric societies of the Early and Middle Holocene in Central Sudan in the view of interdisciplinary research studies.

3 The name of the locality is derived from Khor Shambat - a large wadi stretching from the west to the Nile, around $1.2 \mathrm{~km}$ north of the archaeological research site. 


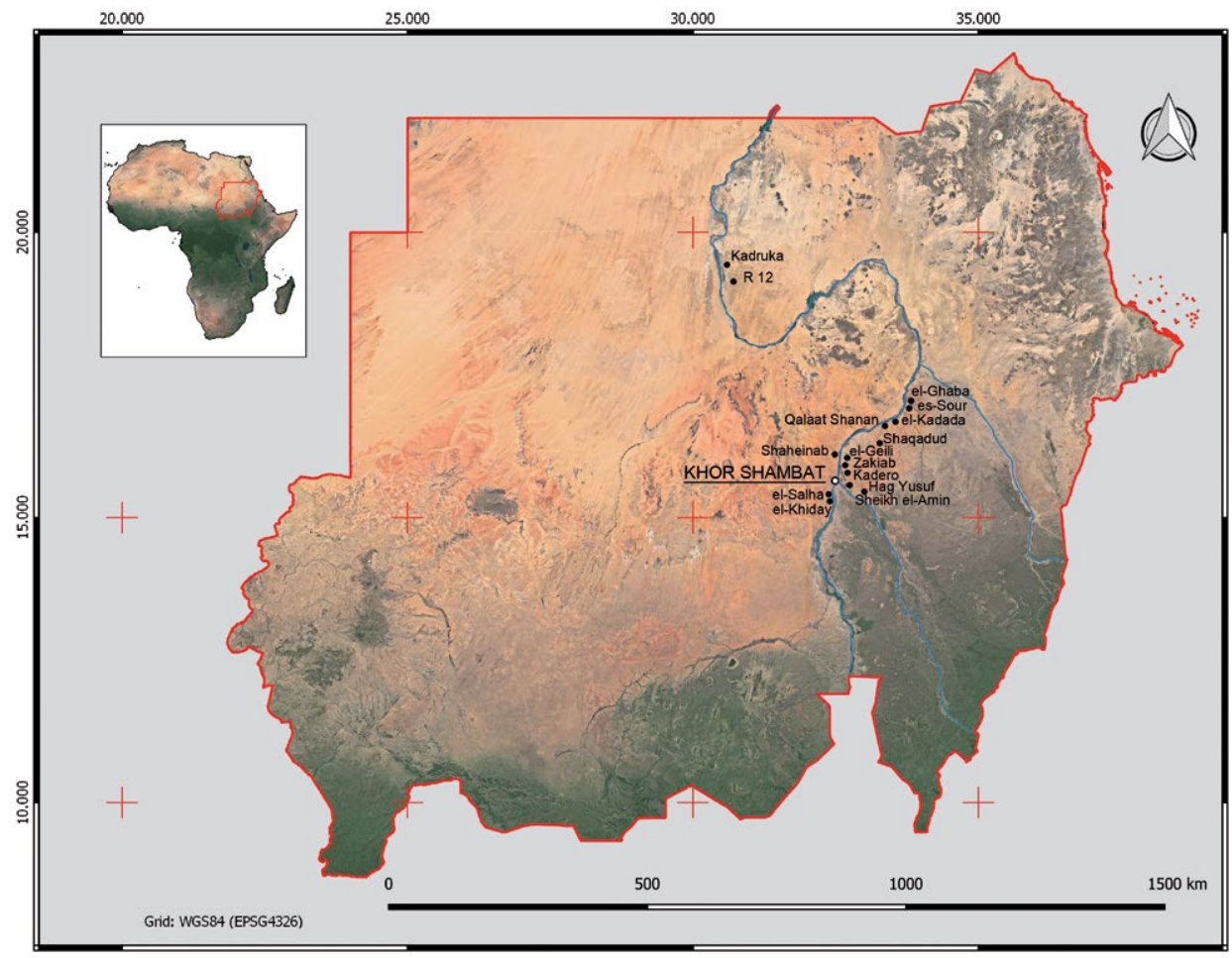

Fig. I. Map of Sudan featuring Khor Shambat and other sites mentioned in the text. Drawn: P. Wiktorowicz and M. Jórdeczka.

\section{CHRONOLOGY OF THE SITE}

The archaeological material collected during the research, the pottery in particular, allowed us to define the chronology of the settlement at KSH 1 in the period between the Early Mesolithic and Late Neolithic. This has been confirmed by a series of radiocarbon dates, which fall within the range of $7000-3200$ cal BC. ${ }^{4}$ As mentioned above, the site also contains remains left by later (Meroitic and Post-Meroitic) cemeteries, yet there are no traces of settlement from these periods.

Most of the Neolithic ceramics from Khor Shambat share features common for the Early Neolithic in Central Sudan. Only a few fragments found in the upper layers

4 The oldest Mesolithic date come from the Feature $14-7950 \pm 40$ BP; $7027-6756 \mathrm{cal} \mathrm{BC}$ at $1 \sigma$ (Poz-103040). 
I38

M. Jórdeczka, E. M. Stanaszek, P. Bobrowski, M. Chtodnicki and I. Sobkowiak-Tabaka

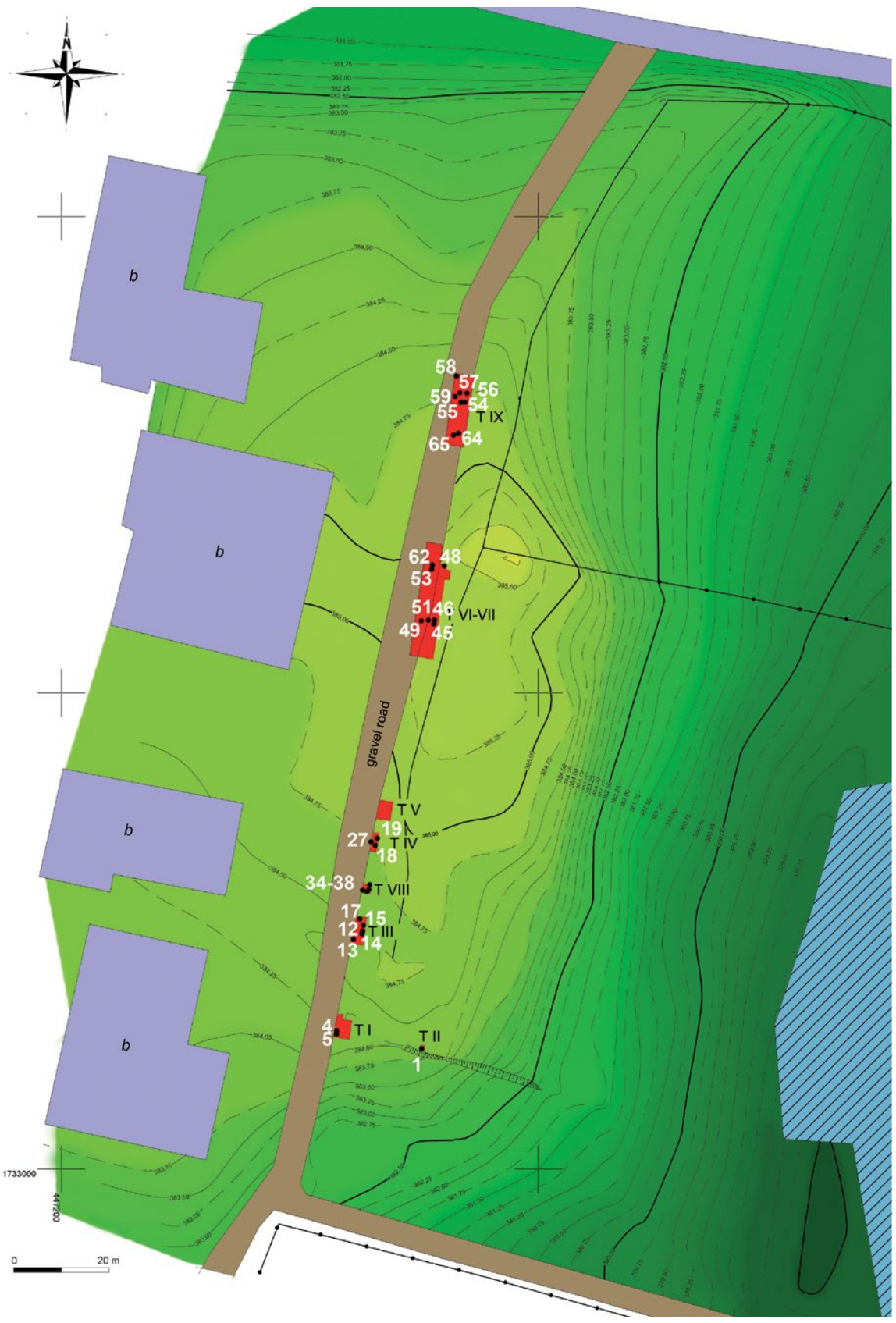

Fig. 2. Map of Khor Shambat showing location of Trench VIII. Drawn: P. Wiktorowicz and M. Jórdeczka. 
of the site are characteristic for the late phase of the Neolithic (burnished pottery, delicately shaped vessel necks, edge shaped into an external lip with a zigzag decoration).

In general, the set of vessel decorations observed at Khor Shambat does not significantly differ from the decoration known from other Neolithic sites in Central Sudan (horizontal parallel incised lines, concentric incised semicircles, dotted zigzag, rocker stamp with uneven edge). We mainly see differences in the proportions of the occurrence of individual decorative motifs or the percentage of undecorated ceramics. We can find analogies at sites such as Sheikh el-Amin on the Blue Nile (Fernandez et al., 2003), Kadero (Krzyżaniak 1984), El-Geili (Caneva 1988), esh-Shaheinab (Arkell 1953), el-Ghaba (Lecointe 1997; Salvatori et al., 2016) or es-Sour (Sadig 2008). It seems that the ceramics at Khor Shambat represent all the phases of the Neolithic. Further separation of data according the layers will make possible to estimate the frequency of each type of pottery. Yet this could prove to be a difficult task for the Neolithic at Khor Shambat, due to the many post-deposit disruptions (Mesolithic layers are better preserved here).

It was only in five Neolithic graves that we were able to record ceramics that were without a doubt a part of the burial goods and thus could be a basis for the definition of the chronology. Dating based on ceramics is not, of course, very accurate, but with all probability, the site's chronology falls within the period between 4400 and 4100 BC. The determination quoted above regarding the chronology of the Neolithic settlement and cemetery is reflected in eight radiocarbon dates (Fig. 3). They originate from Feature 1 and graves $6,13,38,46,51$ and 62 . Unfortunately, due to the lack of collagen, we were not able to perform dating directly from human bones. They samples dated were mostly obtained from charcoal found in the burial pits (in the case of grave 51, it was found in a vessel); in two cases (graves 13 and 38), these were Chambardia rubens shells which constituted the burial goods. The issue here lays in the fact that the reservoir effect needs to be considered and as a result, the determination of the age of the sample is heavily burdened by a margin of error which may reach several hundred years (see Moreton etal., 2004; Kabaciński 20II; Philippsen 2013; Stein etal., 20I3; Jórdeczka et al., 2020).

\section{THE CEMETERY}

The Neolithic inhabitants of Khor Shambat buried their dead within the site (Fig. 2). Although the state of research does not allow us to fully assess the spatial organization and the extent of the cemetery, especially in the eastern and western part of the site (damaged and built over by contemporary buildings), along the $\mathrm{N}-\mathrm{S}$ line we can find graves extending across the entire area of the Neolithic site. 
To date, we have investigated 66 graves of varied chronology - the oldest two are associated with Mesolithic settlement, and the latest with the Post-Meroitic activity. Looking at the overall numbers, nearly half of the graves are probable and certain Neolithic burials (within which we can define five of them as such with a certain degree of probability). An issue here is the lack of burial goods and the state of preservation of part of the burials, which have been destroyed as a result of the effects of postdeposit processes.

It is true that a large part of the Neolithic site and cemetery had been affected by heavy erosion, yet the greatest damage, aside from the modern activity mentioned earlier, was done by Post-Meroitic communities, who had chosen the hill in Khor Shambat as the place where they would bury their dead. This commonly encountered practice of building tumulus graves on culminations has led to substantial damage at many prehistoric sites situated on such terrain (see Salvatori 2012: 406-408). Therefore, finding a stratified site dated in the Early or Middle Holocene in Central Sudan is very difficult.

Part of the graves have already been presented in a report describing the research conducted in 2012 (Bobrowski et al., 2016), while four pot burials appeared in a separate detailed publication (Jórdeczka etal., 2020) along with the burial of male who had a trepanation of the skull performed.

Neolithic graves appear on different levels, anywhere from $20-30 \mathrm{~cm}$ below the current surface (in the southern part of the site) to depths exceeding $1.5 \mathrm{~m}$ in the middle section. Best preserved were the burials at greater depths, often set in sterile earth of eroded iron-rich sandstone. In these cases, we can clearly observe an oval pit, with a diameter within the range of $0.6 \mathrm{~m}$ to $\mathrm{I} .0 \mathrm{~m}$ (Fig. 4). It is much more difficult to distinguish the shape of grave pits set only in silty-sand cultural layers. In this case, we are dealing with relatively shallow oval pits with diameters of $0.7 \mathrm{~m}$ to I.I $\mathrm{m}$.

It is difficult to assess whether there is an association between the depth of graves and their chronology, mainly due to the small number of radiocarbon dates and burials with grave offerings. We can only assume that the graves buried in the cultural layers are later than the layers themselves.

The deceased were buried in a flexed position, on the right (I7) or left side (7), with the head directed most often W (Io), rarely NW or SW, S or E (Fig. 4; Table I). In one case (GR 13), the position of the skeleton may suggest that the deceased was buried in an undefined organic package (shroud). 
Neolithic Inhabitants of Khor Shambat 1, Sudan | I4I

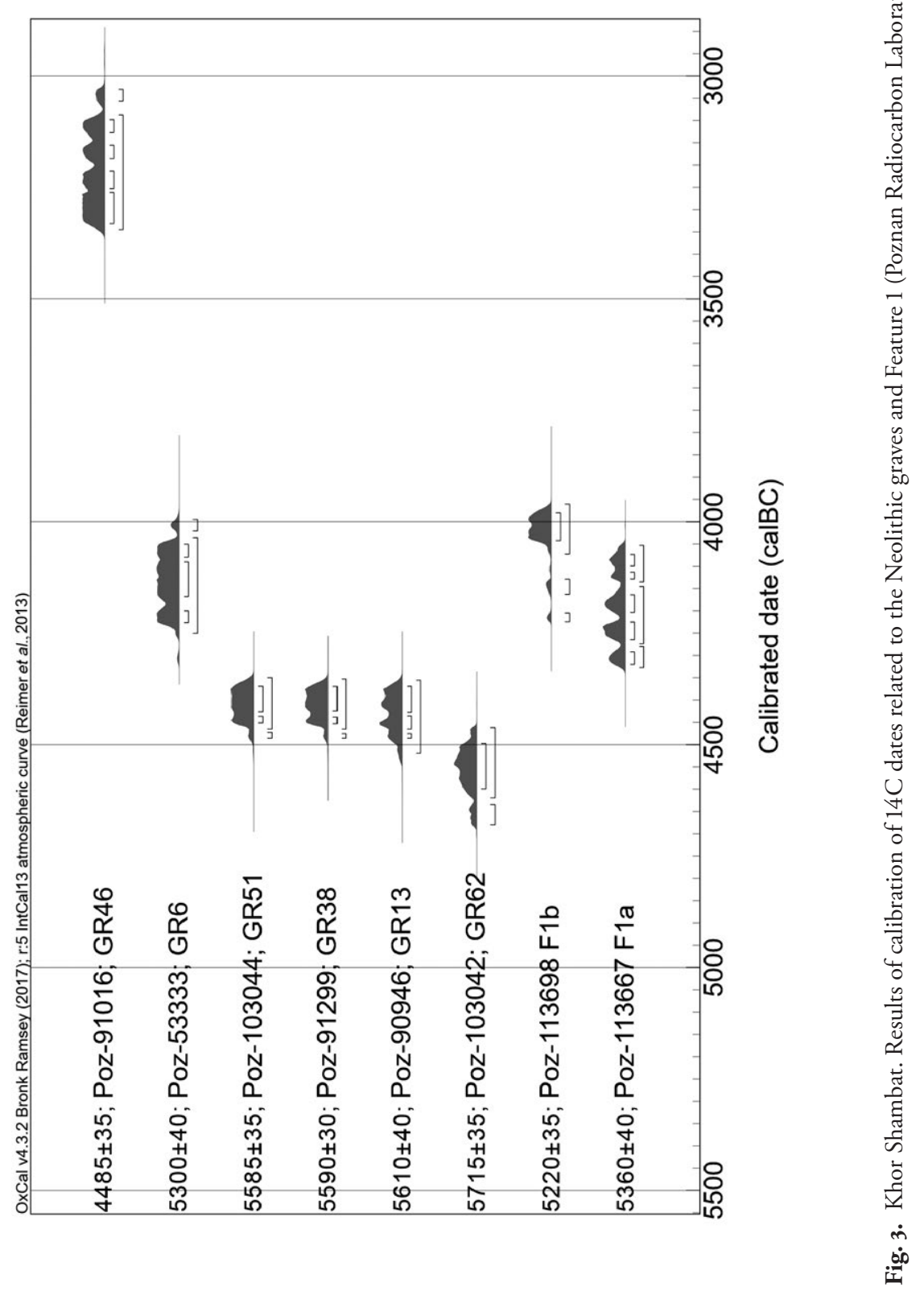


I42 $\mid$ M. Jórdeczka, E. M. Stanaszek, P. Bobrowski, M. Chtodnicki and I. Sobkowiak-Tabaka

\begin{tabular}{|c|c|c|c|c|c|}
\hline 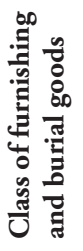 & $\neg$ & $\neg$ & 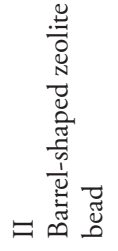 & $\neg$ & 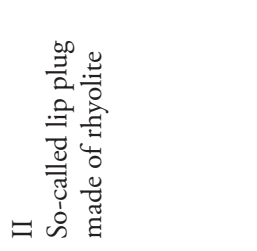 \\
\hline 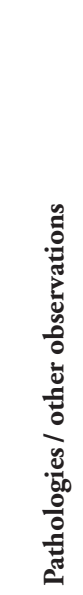 & 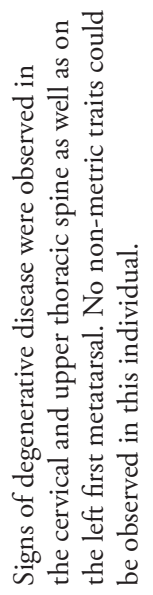 & 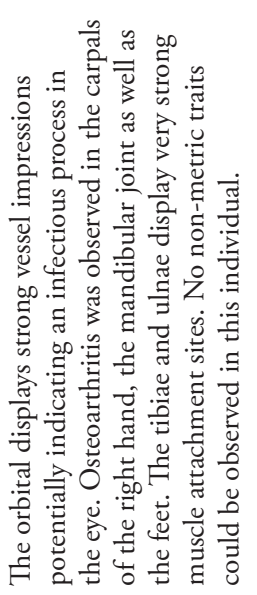 & 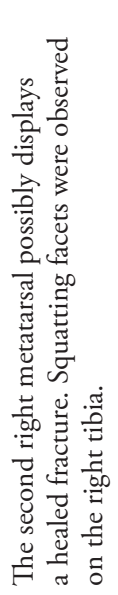 & 1 & 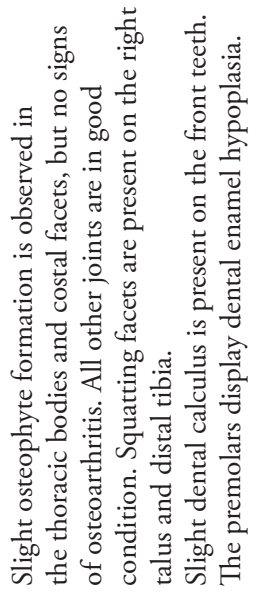 \\
\hline 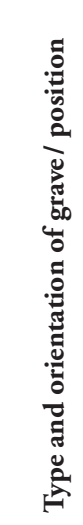 & 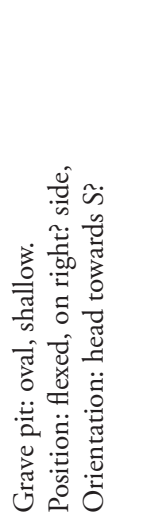 & 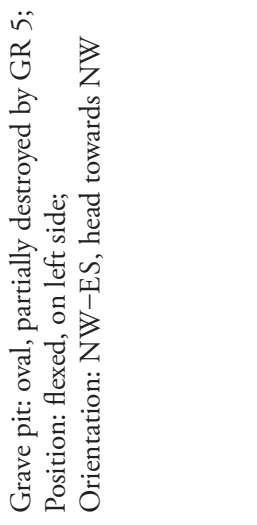 & 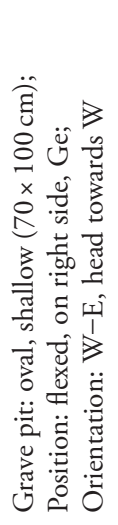 & 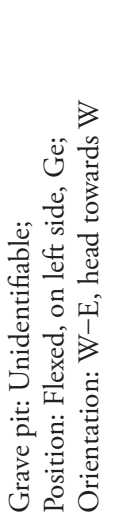 & 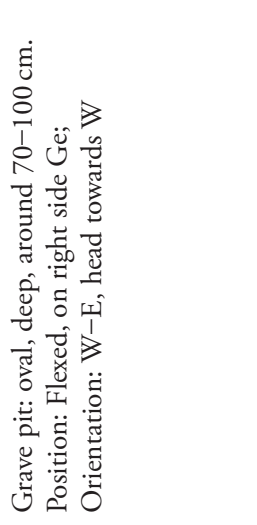 \\
\hline$\underset{4}{\mathscr{K}}$ & $\frac{3}{\frac{3}{8}}$ & $\frac{3}{\frac{3}{3}}$ & 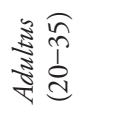 & $\stackrel{\Xi}{\stackrel{I}{I}}$ & 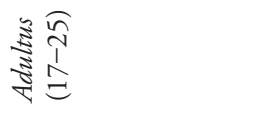 \\
\hline ら & $\Sigma$ & $\Sigma$ & $\Sigma$ & 1 & $山$ \\
\hline ப் & - & 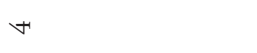 & $n$ & $\bullet$ & $\simeq$ \\
\hline$\ddot{z}$ & - & $\sim$ & $m$ & 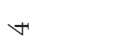 & in \\
\hline
\end{tabular}




\begin{tabular}{|c|c|c|c|c|c|}
\hline 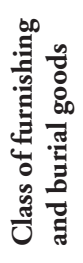 & 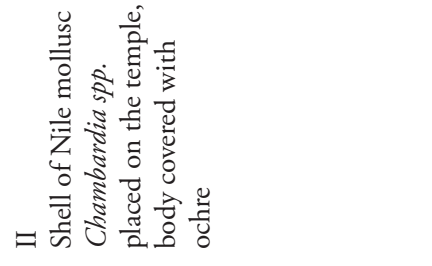 & & 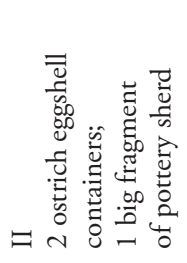 & $\neg$ & 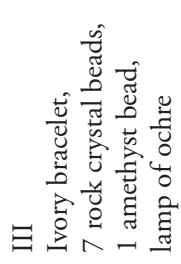 \\
\hline 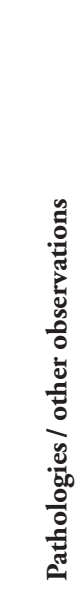 & 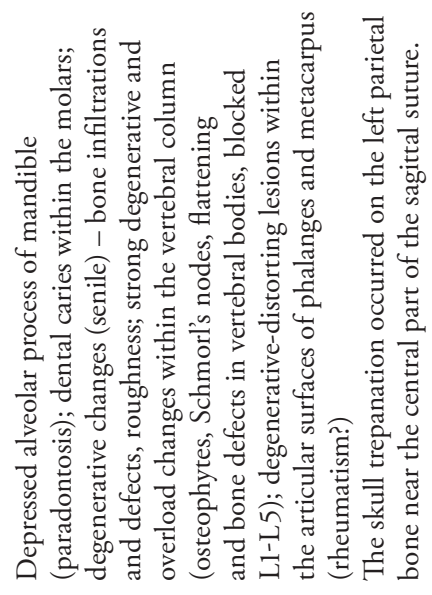 & 1 & 1 & 1 & 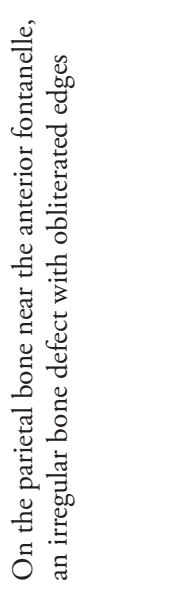 \\
\hline 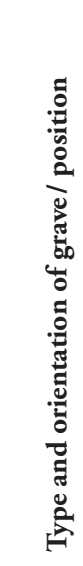 & 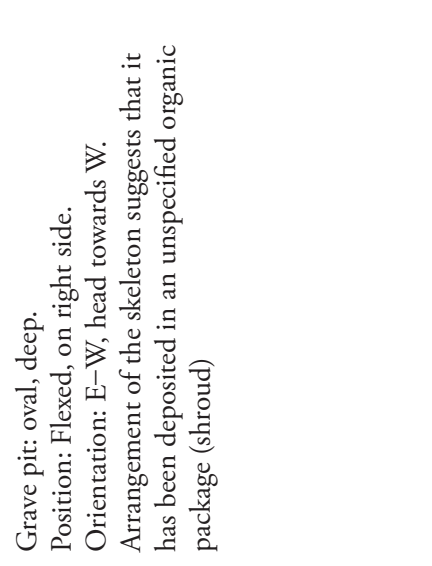 & 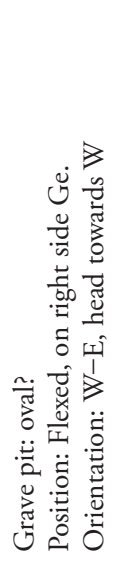 & 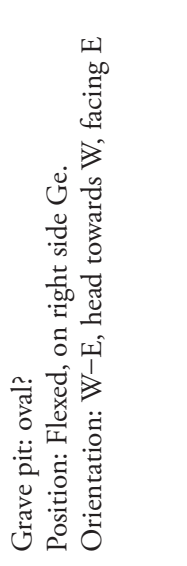 & 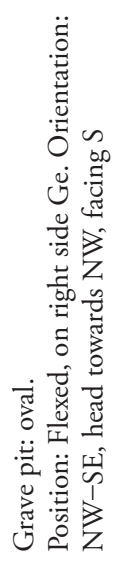 & 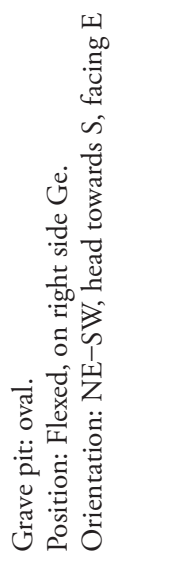 \\
\hline 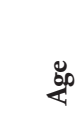 & 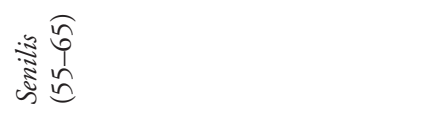 & $\frac{\sqrt{2}}{\sqrt{5}} \sqrt{t}$ & 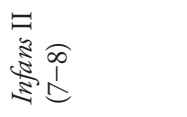 & 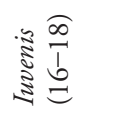 & 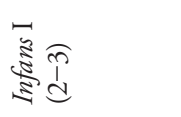 \\
\hline ڤ్ & $\Sigma$ & 1 & $\tilde{\Sigma}$ & 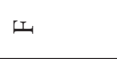 & \\
\hline ப் & $\stackrel{n}{\longrightarrow}$ & \pm & $\cong$ & $\beth$ & $\stackrel{\infty}{=}$ \\
\hline z & $\bullet$ & $\wedge$ & $\infty$ & $a$ & \\
\hline
\end{tabular}


I44 | M. Jórdeczka, E. M. Stanaszek, P. Bobrowski, M. Chtodnicki and I. Sobkowiak-Tabaka

\begin{tabular}{|c|c|c|c|c|c|c|c|}
\hline 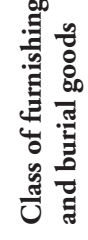 & 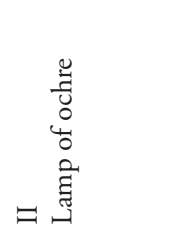 & - & 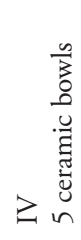 & 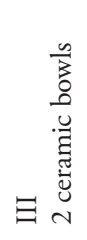 & 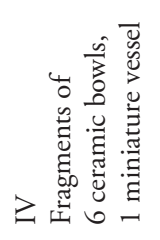 & 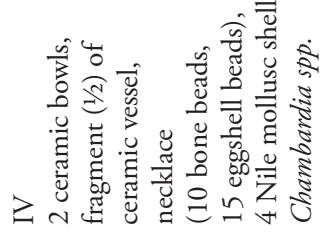 & $\neg$ \\
\hline 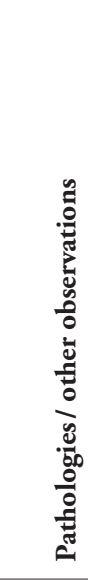 & 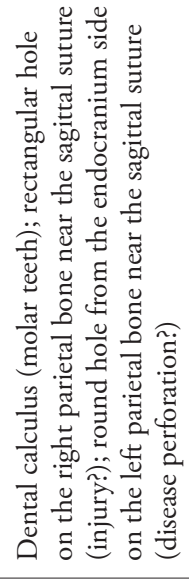 & 1 & 1 & 1 & 1 & 1 & 1 \\
\hline 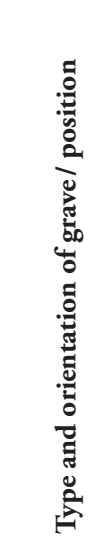 & 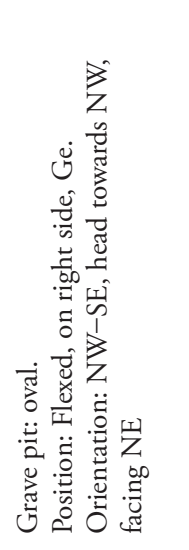 & 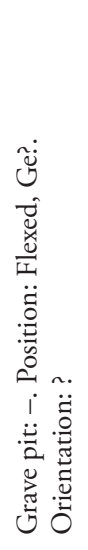 & 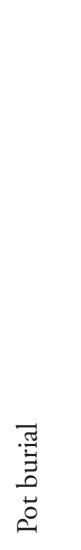 & 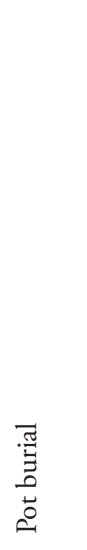 & 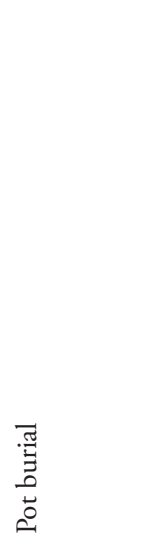 & 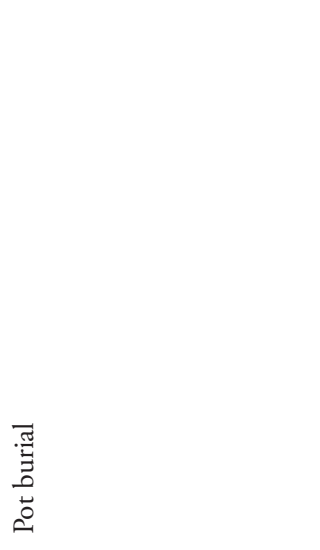 & 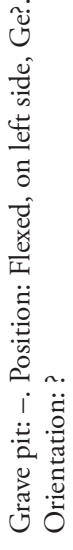 \\
\hline$\frac{8}{4}$ & 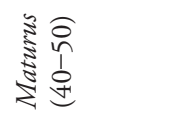 & 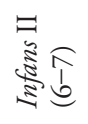 & $\frac{3}{2}$ & $\frac{3}{2}$ & $\frac{3}{2}$ & 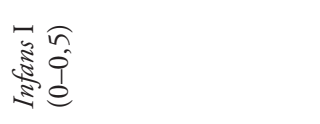 & $\exists$ \\
\hline 心 & $\Sigma$ & & & & & & $\tilde{\Sigma}$ \\
\hline ப் & $\beth$ & $\widehat{\imath}$ & tw & $\approx$ & $\hat{n}$ & $\stackrel{\infty}{\infty}$ & $\nLeftarrow$ \\
\hline$\stackrel{8}{z}$ & $=$ & $\simeq$ & $\stackrel{m}{=}$ & 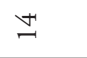 & $\cong$ & $\stackrel{\bullet}{-}$ & $\beth$ \\
\hline
\end{tabular}




\begin{tabular}{|c|c|c|c|c|c|c|c|c|}
\hline 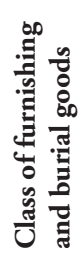 & - & $\neg$ & 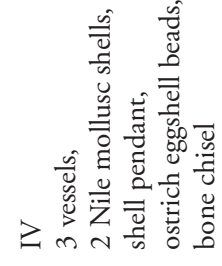 & $\neg$ & 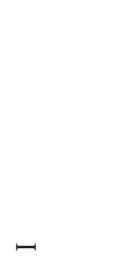 & $\curvearrowleft$ & $\neg$ & $\varpi$ \\
\hline 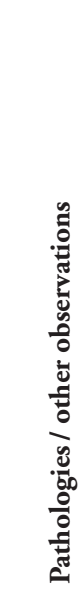 & 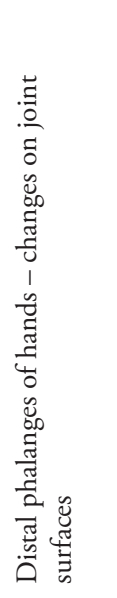 & 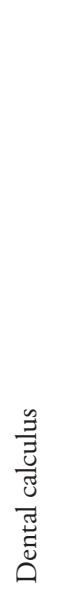 & 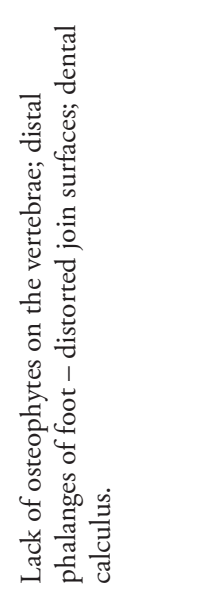 & 1 & 1 & 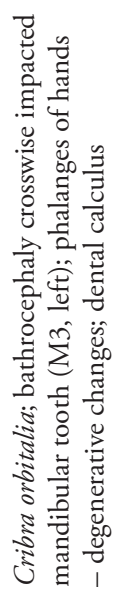 & 1 & 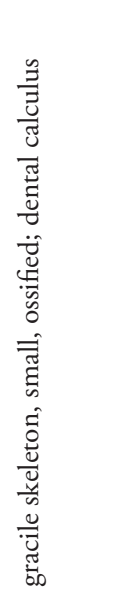 \\
\hline 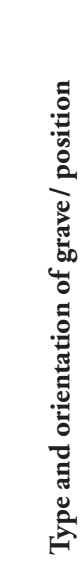 & 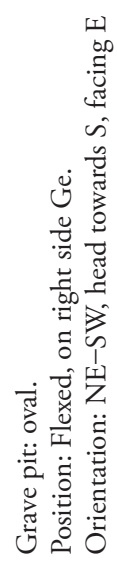 & 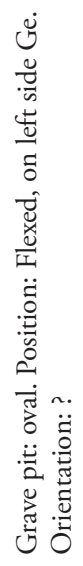 & 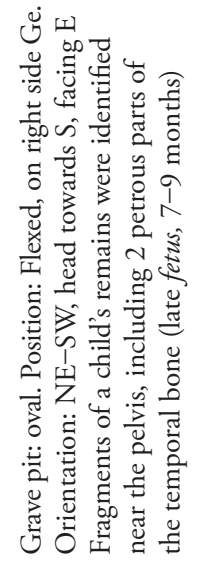 & 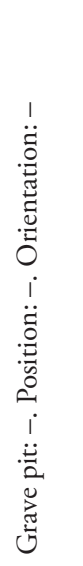 & 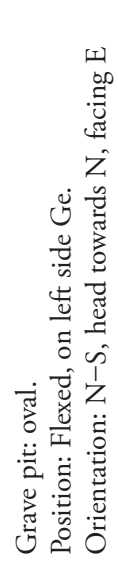 & 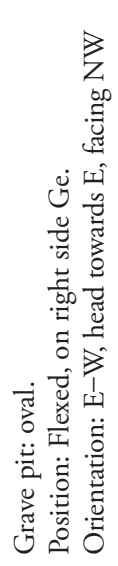 & 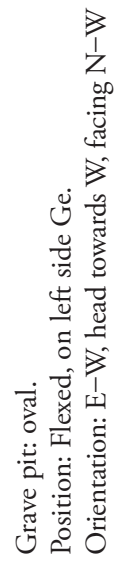 & 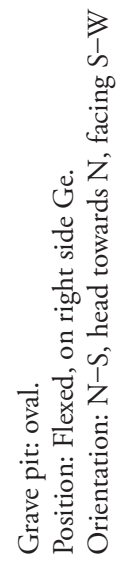 \\
\hline$\underset{\&}{\not}$ & $\frac{2}{3}$ & $\frac{\sqrt{3}}{3}$ & 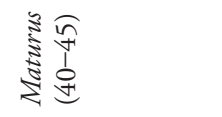 & s: & 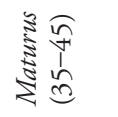 & 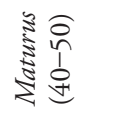 & 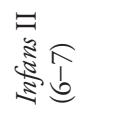 & 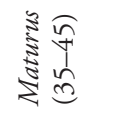 \\
\hline ڤ્ّ & 工 & 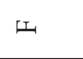 & 山 & & $\Sigma$ & $\Sigma$ & $n$. & 山 \\
\hline ن் & $\stackrel{\infty}{+\rightarrow}$ & જे & $\vec{n}$ & 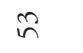 & $\stackrel{*}{n}$ & $\approx$ & $\curvearrowleft$ & $\hat{n}$ \\
\hline$\ddot{z}$ & $\infty$ & $\curvearrowright$ & ㄱ. & $\vec{\sim}$ & ปี & $\ddot{\sim}$ & $\stackrel{\star}{\sim}$ & $\approx$ \\
\hline
\end{tabular}


I46 M. Jórdeczka, E. M. Stanaszek, P. Bobrowski, M. Chtodnicki and I. Sobkowiak-Tabaka

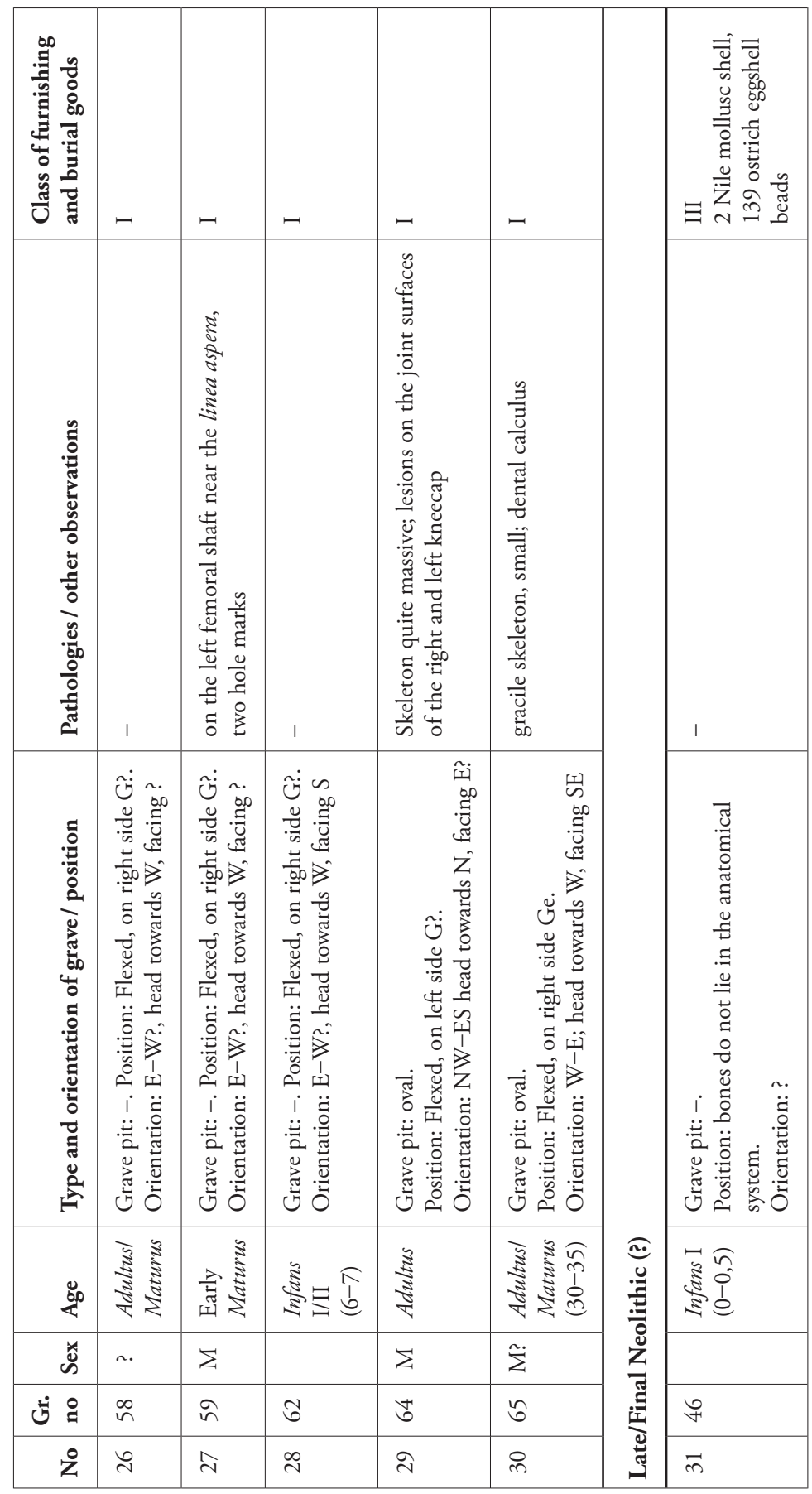




\section{ANTHROPOLOGICAL ANALYSIS}

The primary purpose of anthropological analysis was to estimate the number, sex and age of the deceased, reconstruct the in vivo height of the body, as well as macroscopically record any anatomical pathological changes that leave visible marks on the bones. ${ }^{5}$ The skeletons were analyzed using generally accepted methods and anatomical descriptions of bone structure (cf. Ubelaker 1978; Bochenek and Reicher 1990; Buikstra and Ubelaker 1994; Bass 1995; Piontek 1999; Brickley and McKinley eds 2004; White and Folkens 2005). More detailed analysis was hindered by the generally poor condition of the material:

5 The age at the time of death was determined based on a comprehensive (multi-feature) analysis of changes occurring in the formation of individual morphological features of the bone structure and teeth. Attention was paid in particular to the degree of obliteration of the skull sutures and the condition of the occlusal surfaces of the tooth crowns, while in the case of non-adult individuals, focus was placed on the order of eruption of individual teeth, the degree of bud formation, as well as the formation of the roots. Skeletal ossification, any degenerative changes in the skeletal system, the density of cancellous bone, the wall thickness of marrow cavity in the proximal epiphysis of long bones (femur, humerus) and changes occurring on the surface of the pubic symphysis and auricular surfaces (cf. Acsádi and Nemeskéri 1970; Lovejoy et al., 1985; Brooks and Suchey 1990; Buikstra and Ubelaker 1994; Piontek 1999).

When determining the sex of the deceased, special attention was paid to metric and descriptive differential features in which dimorphism manifests itself to the greatest extent (referring above all to the bearing features of the skull and pelvis bones), in combination with the so-called general morphological impression (cf. Strzałko and Henneberg 1975; Malinowski and Wolański 1988; Buikstra and Ubelaker 1994). At times researchers made use of metric measurements of the thickness and/or diameter of individual bones of the postcranial skeleton and skull, as well as analysed their mass.

All metric measurements were conducted directly at the site (in situ) due to the generally poor condition of the bones, which in did not allow for the same activities to be repeated later. After excavation, the material was strongly fragmented in most cases, which made even the clear identification of individual bones difficult. The presence of an anthropologist at the Khor Shambat site therefore seems indispensable.

A few measurements of metric traits of skeletons were conducted in accordance with the principles of the so-called Martin's technique (Martin and Saller 1957). However, the selection was limited by the condition of the material and the current research needs. Particular focus was placed on the registration of certain craniometric features, as well as on measurements useful for estimating body height. A few non-metric (epigenetic) traits were distinguished using diagrams proposed by A. Czarnetzki (1972).

Reconstruction of the live body height of the bodies of the dead was based on diagrams using comprehensive long bone length measurements (Trotter and Gleser 1952), whereas in the case of incomplete (fragmented) materials, the relationship between the size of the pedicles of certain long bones (femur) and their length was considered, using conversion diagrams developed for this purpose by anthropologists from Poznan (cf. Strzałko et al., 1972: 285).

The analysis of pathological changes was difficult due to the poor condition of the skeletons (abundant post mortem damage, poor degree of fossilization and missing bone parts). The classification of individual diseases and injuries was based on the experiments and diagrams of numerous researchers (Gładykowska-Rzeczycka 1976; 1989; 1994; Ortner and Putschar 1981; Buikstra and Ubelaker 1994; Bass 1995; Ortner 2003). 
I48 $\mid$ M. Jórdeczka, E. M. Stanaszek, P. Bobrowski, M. Chtodnicki and I. Sobkowiak-Tabaka

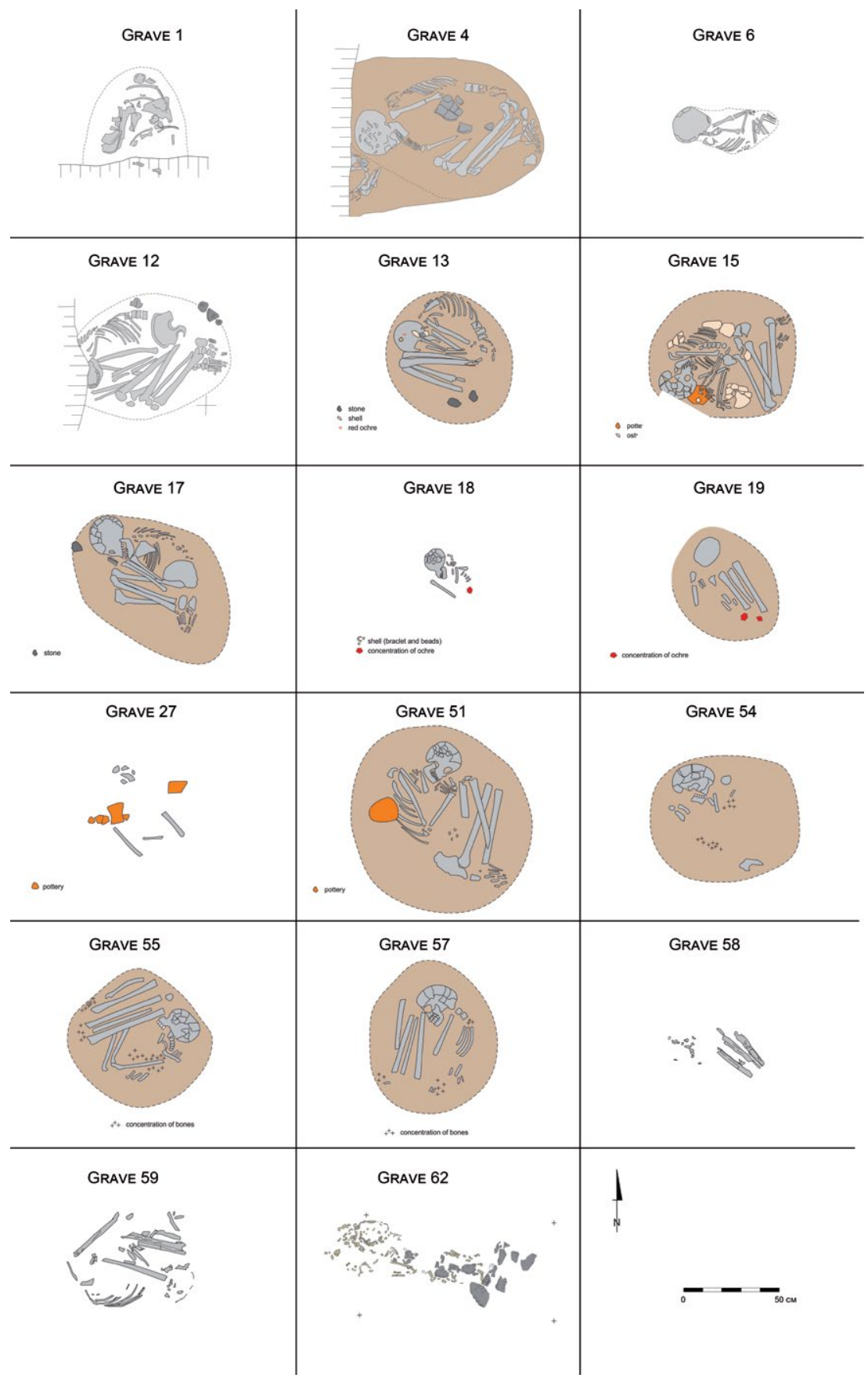

Fig. 4. Examples of Neolithic graves. Drawn: M. Jórdeczka and K. Mugaj. 
fragmentation, missing bones, high fragility associated with a generally poor degree of fossilization and contact with the sun and air during exploration.

In the total number of 30 graves associated with high certainty with the early Neolithic, 17 are graves of adults (Adultus, Maturus and Senilis) including 5 female and Io male, while in two of the cases it was not possible to determine the sex. The oldest individual was a male buried in Grave 13, who lived to around the age of approx. $55-65$ years. One of the women died at the age of Iuvenis ( $16-18)$. Children's burials constituted over $43 \%$ of the graves examined (I3), whereby three of the graves were burials of fetuses in vessels (Jórdeczka et al., 2020); children at the age of Infans I (no older than 6 years) were buried in 5 graves (including one pot grave - Jórdeczka et al., 2020), and the following 5 are burials of children aged Infans II (older than 6 years).

The poor condition of the skeletons hinders the observation of pathological changes (details in Table I), and consequently makes it difficult to draw more detailed conclusions on matters concerning health or living conditions. However, it is worth noting a few of them, such as the discovery of osteoarthritis in the joints of the spine and postcranial skeleton which manifests itself through pitting and eburnation on the joints (Rogers and Waldron 1995) and provides important information on the activity of the studied population. One of the most frequently observed pathologies in adult skeletons is cribra orbitalia. Porotic hyperostosis is a pathological condition that affects bones of the cranial vault, and is characterized by localized areas of spongy or porous bone tissue. It can be a determinant of many diseases associated with iron-deficiency anemia (Stuart-Macadam I99I), as well as a deficiency of a specific ingredient in the diet (e.g., vitamins B9 and Bı2; Zarifa et al., 2016). Lesions in the orbital roof may have been caused by an eye infection (Wapler et al., 2004). Cribra orbitalia could also be the result of malaria (Fairgrieve and Molto 2000; Smith-Guzmán 2015).

In a few cases, researchers were able to observe rheumatic (degenerative) changes in the joint surfaces of the phalanges of the feet and hands (e.g., GR 51, 55) or patella (GR 64), as well as diseases of the spine associated with the degenerative process that would have developed with age. Overload pathologies (flattening of vertebral bodies, Schmorl's nodes) were also observed.

Dental analyses also provide valuable information on eating habits, occupational habits, as well as general hygiene and health. Calculus was often detected on the teeth of the deceased buried in Khor Shambat. Analyses of dental plaque were performed at the Prehistory Department of the Autonomous University of Barcelona. The dental calculus results indicate the consumption of grasses, including panicoids that were also noted in the groundstone assemblages, in addition to other plant foods such as edible wild fruits that were presumably consumed as well (additional information will be provided in a separate article to be published in 2020). 
Among the burials of adults, the grave of a male in the age of senilis (GR 13) is of particular importance. On his skull, researchers observed one of the oldest cases of therapeutic or magical trepanation in North East Africa. Special photographic documentation (macroscopic observation), binocular as well as X-ray (RTG) photographs were made for specialist studies related to craniotomy surgery, facilitating the qualitative assessment and interpretation of the find (under study). The skull trepanation occurred on the left parietal bone near the central part of the sagittal suture. On the bone margin of the trepanation hole, slight traces of healing were visible which suggests that the operation could have been unsuccessful. A shell of a Nile mussel was placed on his temple, and the body was covered with ochre.

A case observed in grave 51 was an exceptional discovery (Fig. 5); here a mature female ( $40-45$ years) was buried with her unborn child (the fetus was about $7-9$ months old) in the womb (fragments of the child's remains were identified in the pelvic area, including 2 petrous parts of the temporal bones). ${ }^{6}$ Death during childbirth was probably a common case in the past, ${ }^{7}$ but one very rarely documented by archaeologists. Only about 20 such cases have been published in literature to date (e.g., Hawkes and Wells 1975; Wells 1978; Owsley and Bradtmiller 1983; Pounder et al., 1983; Persson and Persson 1984; Malgosa et al., 2004; Rascon Perez et al., 2007; Cruz and Codinha 20IO; Willis and Oxenham 20I3), and one of the oldest is the grave at the Lokomotiv cemetery in southern Siberia; its age is estimated at 7000 to 8000 years (Liverse etal., 20I5), while the majority of known cases are much younger. A lack of osteophytes on the vertebrae, distorted join surfaces on the distal phalanges of foot, as well as dental calculus was observed on the skeleton of the mother. This grave was also among the best furnished at the Neolithic cemetery (more details follow below).

Genetic testing samples were also taken from all skeletons for which this was possible based on their condition of preservation. Efforts were made to take samples of undamaged teeth, or when that was not possible, fragments of long bone shafts and petrous parts of the temporal bones. These efforts were limited each time by the condition of bone material and teeth which was not always satisfactory. Unfortunately, researchers were unable to obtain any good nuclear DNA from any sample; however in a few cases attempts will be made to obtain mitochondrial genomes.

6 The burial of a female in advanced pregnancy is also known from recent research in Kom Ombo, but it is dated at around 3700 years (https://www.nationalgeographic.com/culture/2018/11/ancient -egypt-pregnant-woman-burial-archaeology/).

7 An example is the study of pre-Columbian female mummies from Chile, which showed that about I $4 \%$ of women of childbearing age died due to perinatal complications, while only $17 \%$ were not able to bear children at all (Arriaza et al., 1988; Liverse et al., 2015). 

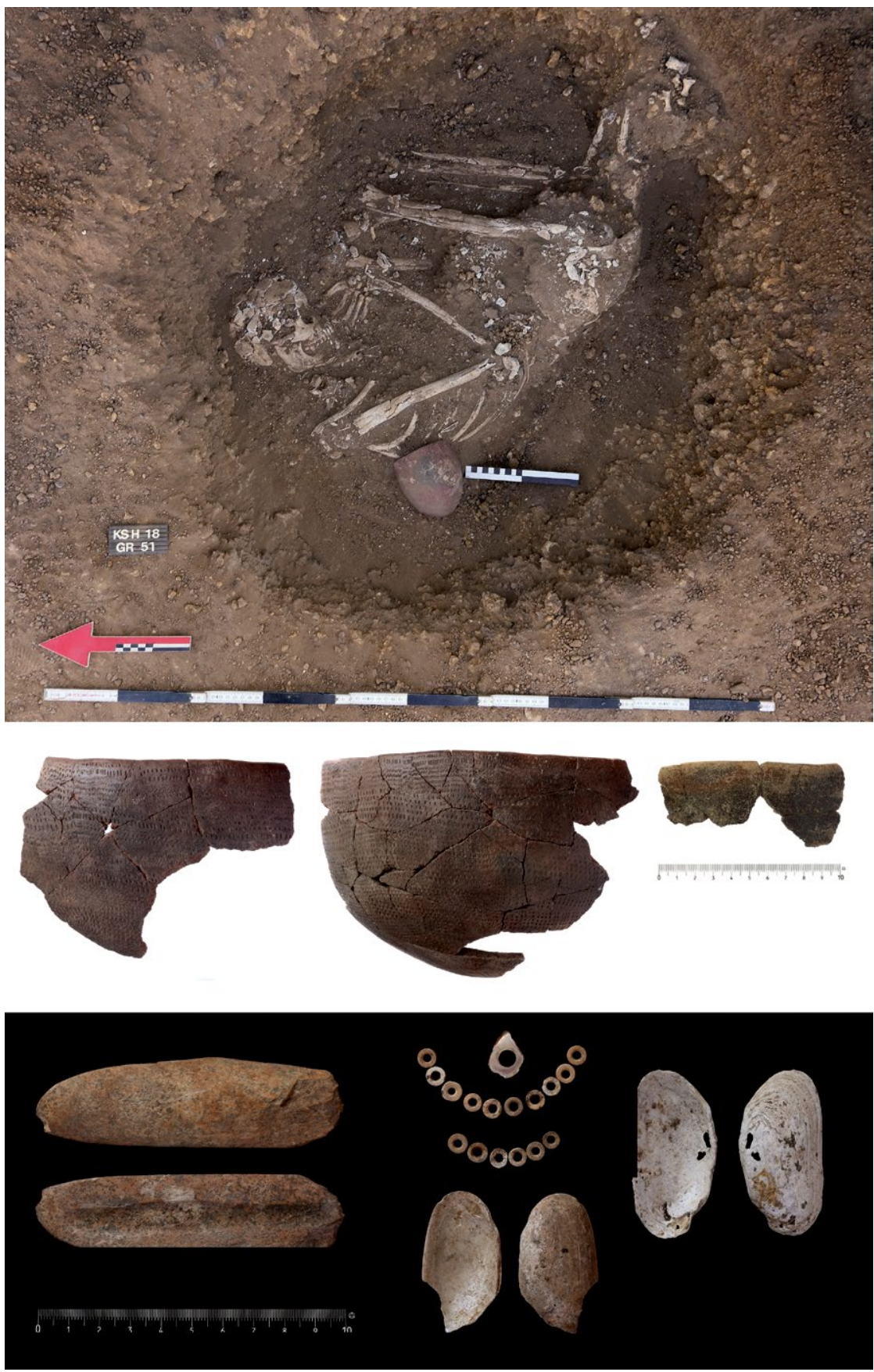

Fig. 5. Grave 51. Photo: M. Jórdeczka. 


\section{BURIAL GOODS}

The quality of burial goods in Neolithic graves in Khor Shambat is worth noting. At the burial site of Khor Shambat, $40 \%$ of all Neolithic inhumations contained offerings. However, if we consider only the graves of adults, this proportion falls to less than $30 \%$, with the majority being single grave gifts (Class II). ${ }^{8}$

The adult female in GR 2 was buried with a rhyolite stud/lip plug which has a rarely seen hourglass-shaped longitudinal section (Bobrowski et al., 20I6: 46I). The adult male burial from GR 5 was provided with a small $(\mathrm{I} 5 \times 8 \mathrm{~mm})$ barrel-shape bead made of zeolite (Bobrowski et al., 20I6: 46I) and Nile molluscs shell Chambardia spp. was found on the temple of the skull of a senilis male from GR 13 (his body was covered with ochre; Fig. 6). This type of shell had arguably been of exceptional meaning to communities at the time and were observed at many Neolithic sites as well and not only in the territory of Sudan and Egypt (Bar-Yosef 2002; Krzyżaniak 20II; Gautier and Van Neer 20II; van den Brink etal., 20I5). A single lamp of ochre was found in a maturus male grave (GR 19).

The above-mentioned burial of a female who died in advanced pregnancy (GR 51; Fig. 5) had an exceptional group of burial equipment. Her grave contained three ceramic vessels: an egg-shaped, deep bowl with a straight edge, red slip burnished vertically outside; a fragment of an undecorated bowl with a simple edge, burnished, originally covered with a red slip; and fragments of an almost complete, large bowl with a simple edge. In the latter case, the outer surface was brown, covered with a dense zigzag dashed line, the fracture was dark brown with a grey core. Fragments of this vessel, found on the top of the grave pit, were used as a digger to dig the burial pit, as indicated by the smoothing on the edges of the fractures. In addition to the vessels, the grave also contained two Nile mussel shells, ostrich egg beads, a shell pendant and a bone chisel. ${ }^{9}$ These exceptional burial goods may be related to the particularly special treatment of fetuses/children by the early Neolithic communities in Khor Shambat.

In the burials researched to date, $46 \%$ of the children, and $100 \%$ of fetuses have burial goods, and in every case these gifts are very rich (Class III and IV). The burials of fetuses from Khor Shambat are moreover in line with the tradition of burials in ceramic pots, known only from three other sites in Sudan in the Shendi Reach: es-Sour (Sadig 2008; 20I2; 20I4), el-Kadada (Geus 1984b; Reinold 2007) and Qalaat Shanan (Hamd 20I2; 20I5; Ahmed and Bakry 20I7). This is one of the most widespread and at

8 Classification of graves on the basis of equipment: Class I - no furnishing; Class II - single offering; Class III - up to 3 offerings (pottery vessels of fine and/or utility ware, beads forming a necklace, bracelet, a sandstone palette, small lumps of ochre); Class IV -3 and more pottery vessels, personal adornments and associated implements, tools (based on Krzyżaniak 20II).

9 Material under study. Additional information will be provided in a separate article to be published in 2020 . 


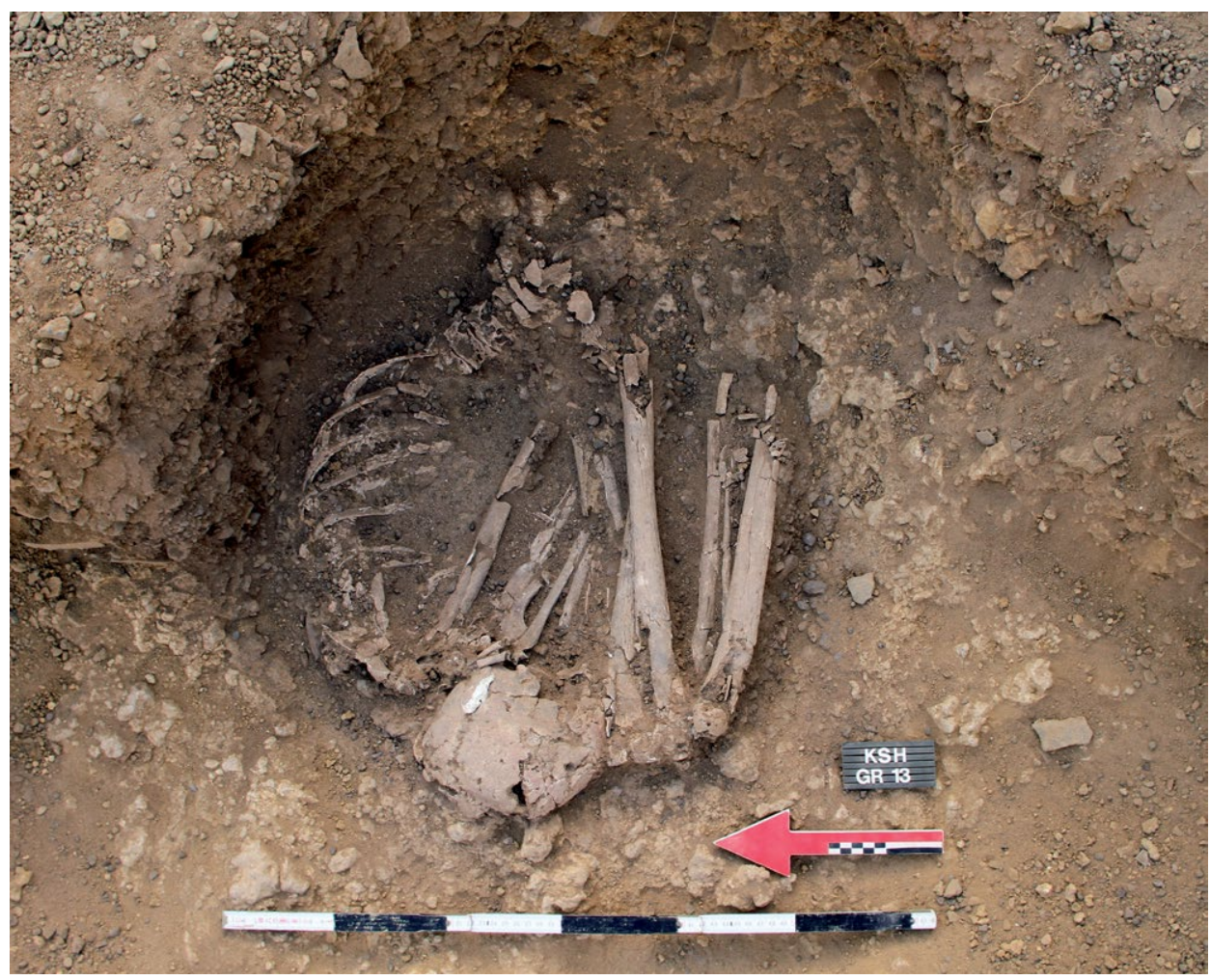

Fig. 6. Grave 13. Photo: M. Jórdeczka.

the same time, most intriguing funeral practices in prehistory, with its oldest examples dated to the end of the 7th and early 6th millennia BC (Streit 2016: 172) we can find this in the northern Levant (Bacvarov 2008). In Egypt, this tradition appeared much later, somewhere around $3500 \mathrm{BC}$ (Power and Tristant 2016: 1476). Examples of burials in vessels known from Central Sudan are also older, reaching the second half of 5 th millennium BC, which may indicate that either this burial practice emerged on a local level or that it had spread from the Levant on a route other than Egyptian. The pot burials in Khor Shambat (Gr 34, 35, 37, 38 - Fig. 7) were found next to a post-Meroitic grave in a trench with an area of $4 \mathrm{~m}^{2}$ (Jórdeczka et al., 2020). The vessel type ceramics as well as the radiocarbon date suggest a date of around 4400-4IOo BC.

Also worth noting is the burial of a child aged I-2 years (GR 18; Fig. 8), in which an irregular bone defect with obliterated edges was observed on the parietal bone, near the anterior fontanelle. Placed beneath his body was an ivory bracelet, about $67-72 \mathrm{~mm}$ in diameter, $29-3 \mathrm{I} \mathrm{mm}$ wide and $3-4 \mathrm{~mm}$ thick. The burial goods of the grave also 
$\mathrm{I} 54$

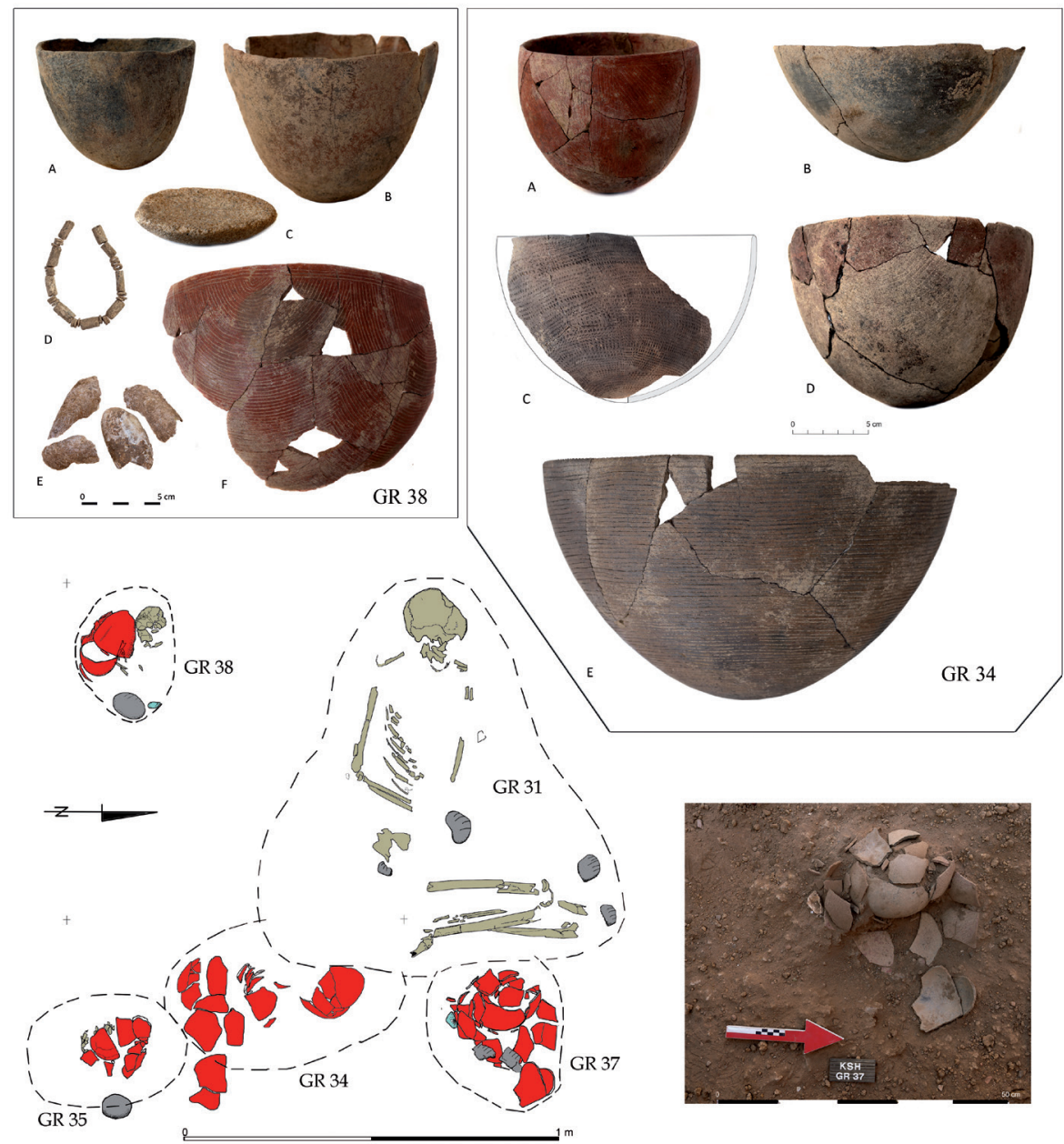

Fig. 7. Trench VIII. Neolithic pot burials (and examples of the offering) and Post-Meroitic grave. Drawn and photo: M. Jórdeczka (see Jórdeczka et al., 2020).

included seven very well-made beads made of rock crystal and I made of amethyst, all with fully polished surfaces. The diameters of the beads ranged from 5.27 to $5.72 \mathrm{~mm}$ and their height from I.8I to $3.06 \mathrm{~mm}$ (amethyst). Holes drilled on both sides had a diameter of 1.56 to $1.84 \mathrm{~mm}$.

On the other hand, two undecorated vessels made from ostrich egg shells were placed in the grave (GR 15; Fig. 9) of a child (probably a boy) aged Infans II (7-8 years 


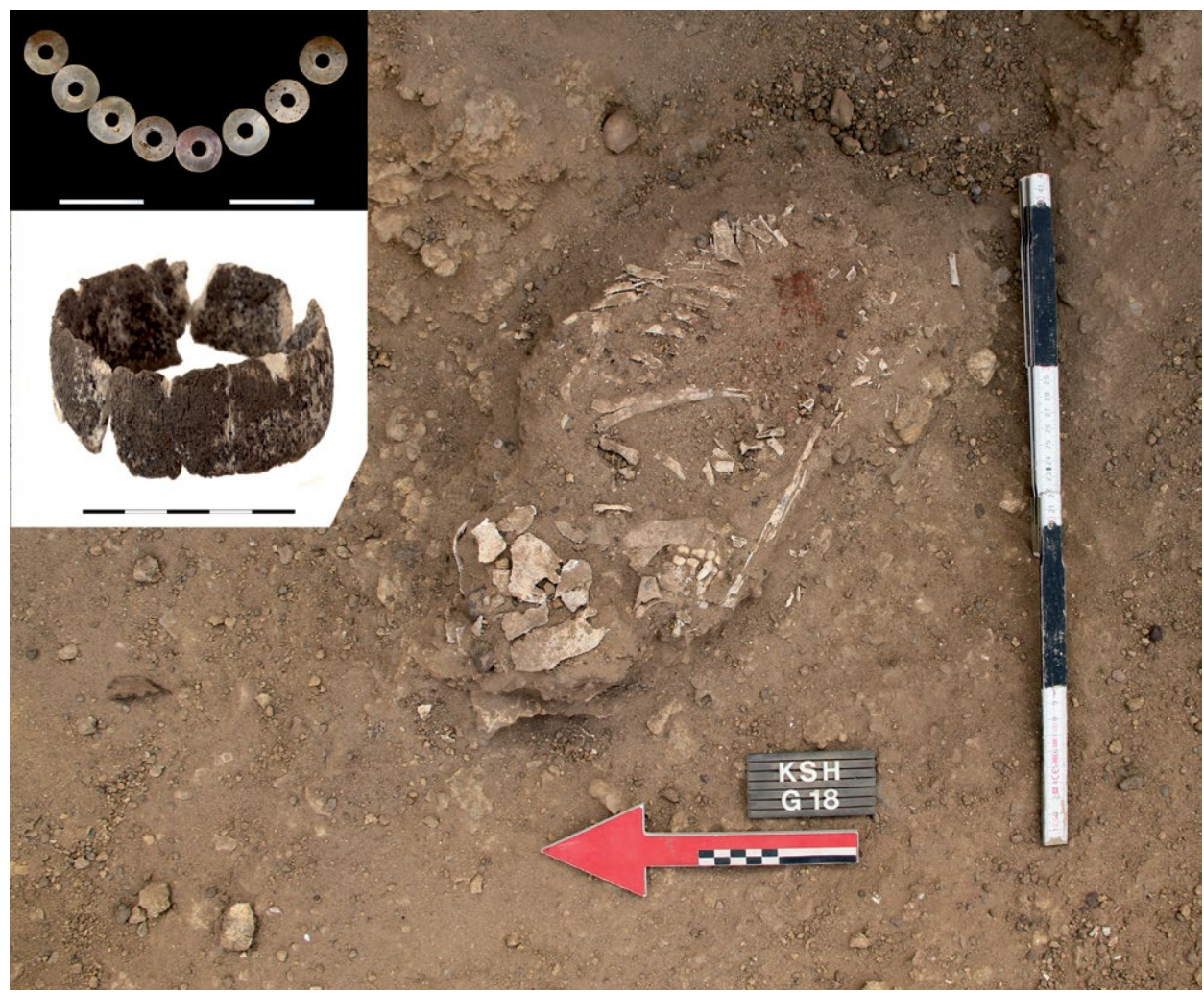

Fig. 8. Grave 18. Photo: M. Jórdeczka.

old). One of them was found between the thighs and forearms, while the other, broken, was near the child's back. Placed under the head was a large fragment of a vessel spout, which came from an open mould with a spout diameter of about $23 \mathrm{~cm}$. The thickness of the walls was $6 \mathrm{~mm}$. The spout was decorated with a grid pattern, while the belly did not have any traces of decoration.

As far as burial goods are concerned, the burial of a child (GR 46) who died at the age of Infans I (o-0.5 years) also deserves our attention. Unfortunately, it was badly damaged, and the bones were not found in anatomical order. In the poorly outlined small pit were found two Nile mussel shells Chambardia spp. and 139 beads from ostrich egg shells of varying diameter, ranging from 4.5 to $9.5 \mathrm{~mm}$ in diameter (Fig. Io). The date obtained from charcoal found in the pit suggests a later, Late Neolithic chronology, but the condition of the grave does not allow the determination of the connection of the charcoal with the burial (Fig. 3). 
I56 M. Jórdeczka, E. M. Stanaszek, P. Bobrowski, M. Chtodnicki and I. Sobkowiak-Tabaka

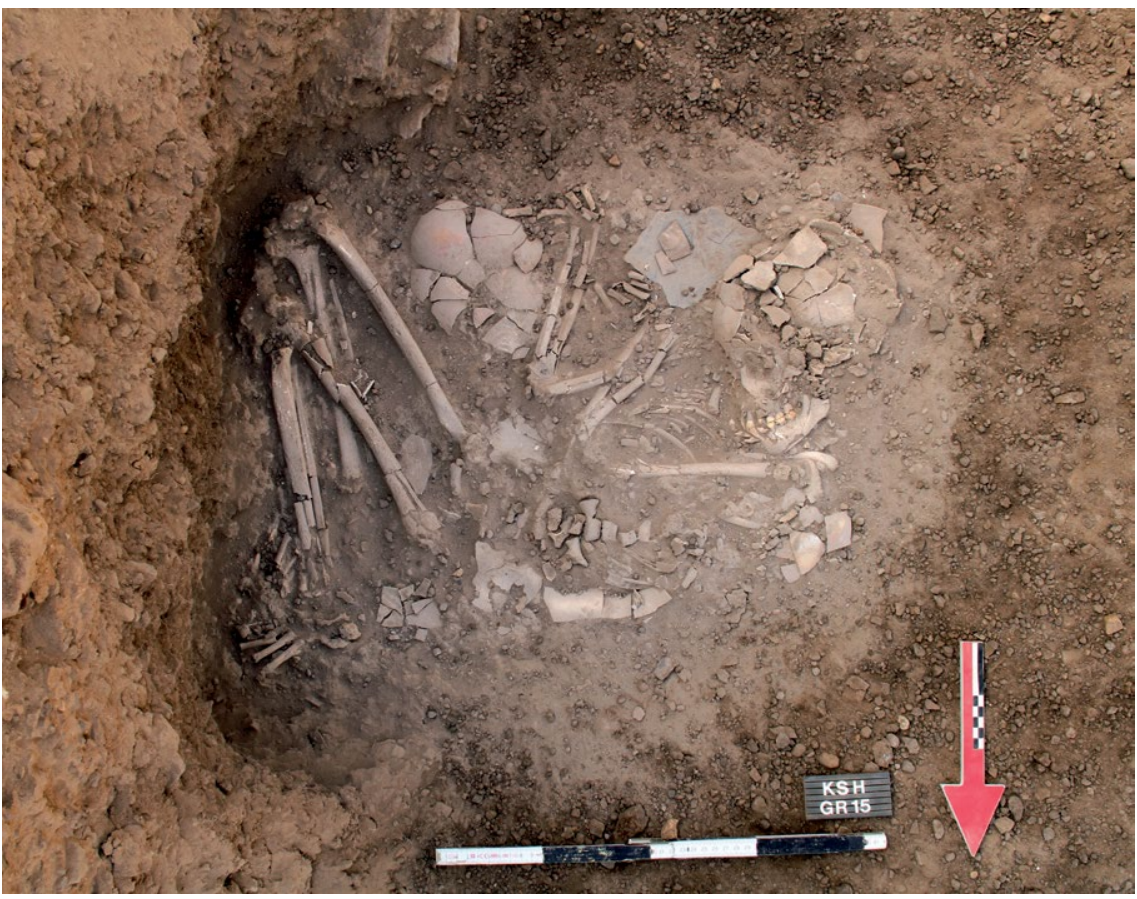

Fig. 9. Grave 15. Photo: M. Jórdeczka.

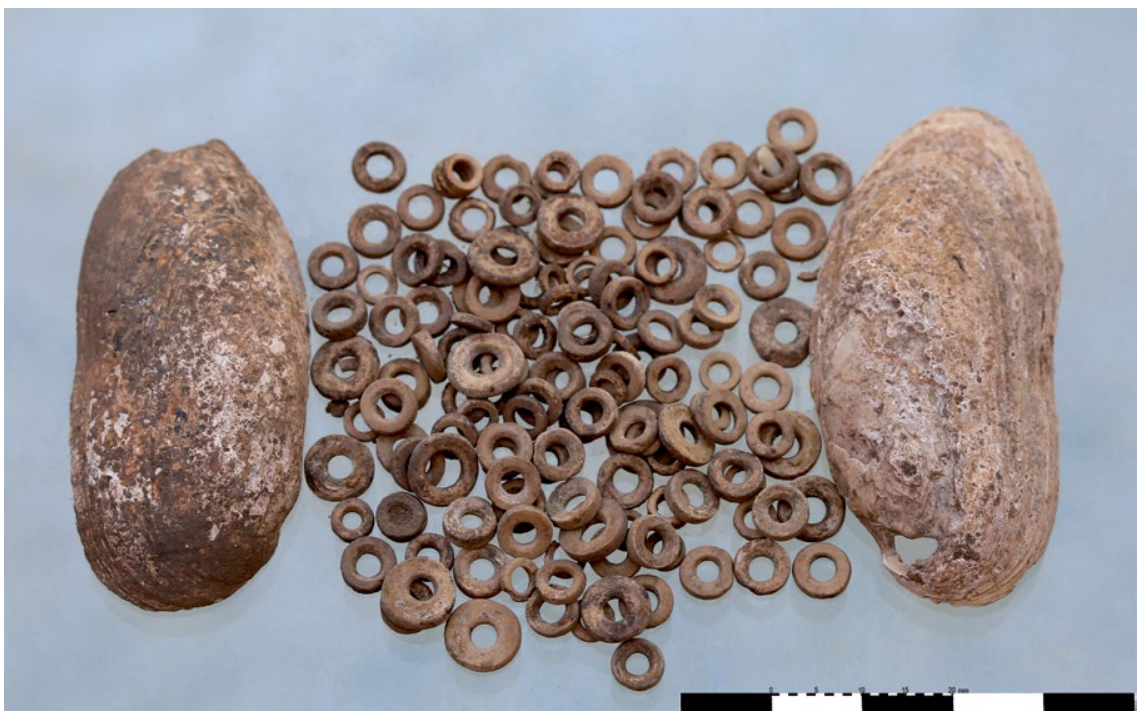

Fig. Io. Grave 46 - burial goods. Photo: M. Jórdeczka. 


\section{KHOR SHAMBAT IN CONTEXT}

Studies of the Neolithic in Central Sudan already have a long tradition. Since the discoveries in Shaheinab (Arkell 1953), many Neolithic sites have been studied, although initially in the 1960s, the key activities of archaeologists were associated with the area affected by the construction of Aswan High Dam and directed to the north of Sudan, into the area of the Second Cataract (Shiner 1968a; 1968b; Nordström 1972). Once those studies were completed, some of the prehistorians moved south and started work in the Southern Dongola Reach area (Hays 1971; 1976; Marks and Ferring 1971; Marks et al., 1986), as well as the Upper Atbara (Shiner ed. 197I) or in the east of Sudan (Fattovich and Piperno 198I). Archaeologists did not return to Central Sudan until the I970s, which is when they discovered the first Neolithic cemeteries.

In 1972, L. Krzyżaniak began research on the Neolithic settlement and cemetery in Kadero situated on the east bank of the Nile. This cemetery, located about $13.5 \mathrm{~km}$ away from Khor Shambat in a straight line, is a perfect reference here. During excavations carried out systematically for nearly 30 years, 248 graves were examined, including 218 Neolithic ones (Krzyżaniak 1975; Chłodnicki et al., eds 20II; Chłodnicki 20I8). Based on radiocarbon dates, the chronology of the Neolithic groups are estimated to be in the range from $4600 \mathrm{cal} \mathrm{BC}$ (northern midden) and $3800 \mathrm{cal}$ BC (southern midden; Chłodnicki and Kabaciński 20I5). Only six dates originate directly from the graves. The oldest, Early Neolithic date 5565 35 BP - 4410 440 cal BC (Poz-4014; Kabaciński 20II: 4I8) was obtained from Aspatharia Sp. shells found in a rich grave of a child (GR 220) deceased at age Infans I (Krzyżaniak 20II: I8I-I82), while the youngest, associated with Terminal Neolithic, is $4 \mathrm{I} 5 \mathrm{O} \pm 30 \mathrm{BP}-2760 \pm 8 \mathrm{o} \mathrm{cal} \mathrm{BC}$ and originates from grave 243 (Kabaciński 20II: 4I7-4I8). At the cemetery in Kadero, 40.7\% of graves contained burial goods, while the large amount of data enabled researchers to conduct a series of observations and distinguish four classes of burial goods. Observations made included the relationship between the type and number of burial goods, and the sex and age of those buried. The burial goods in women's graves were less diverse and more modest. On the other hand, the graves of men and babies (Infans I), though diversified ( $48 \%$ of men's graves had no burial goods), in general had considerably richer and more diverse burial goods. In addition to ceramics and beads (being the main group of burial goods in women's graves), these graves had mace heads, palettes, stone tools or bracelets made of ivory and hippopotamus bones. Worth noting, however, are two graves in which mother and child were buried (GR 97 and 113), and which also had very rich burial goods (Krzyżaniak 20II: I26-I29). What is interesting is that the offerings observed in the graves of older children (Infans II) were not rich, while the graves of juveniles did not have any offerings at all. Based on this information, L. Krzyżaniak proposed theories about the possible social diversity of the population living in the Neolithic settlement in Kadero, and emphasized that the richest graves 
are located in the central part of the site, regardless of chronology (both in the Early Neolithic and the beginning of the Late Neolithic - Krzyżaniak 1992).

Interesting observations were made at the cemetery in el-Ghaba (Geus 1984a; 1984b) discovered in 1977, where a total of 265 Neolithic graves were studied during three excavation seasons (1980, 1985 and 1986). Unfortunately, the lack of a physical anthropologist during the research resulted in the loss of some information, especially regarding the age, sex and live body condition of the buried (Salvatori et al., 2016: 6), which is crucial when trying to reconstruct the spatial distribution of graves and social aspects of the studied populations. Fortunately, it was possible to observe stratigraphic relationships between individual groups of graves. Undoubtedly, this cemetery provided some very important information which proved useful for the reconstruction of the Neolithic process in Central Sudan. Along with data from the R12 site, a new image was obtained showing the utilization of Near Eastern cultigens (emmer wheat and barley) and the collection and/or cultivation of millet already in the second half of the 6th millennium BC (Salvatori and Usai 20I6: I2I).

Khor Shambat 1 gives us the rare opportunity to observe changes occurring between Mesolithic and Neolithic communities. Alongside economic changes, the Neolithic brought many major ideological changes that are reflected in funeral practices. What is also important is that we are probably dealing with nearly continuous occupation at $\mathrm{KSH} 1$ lasting from the beginning of the 7 th millennium $\mathrm{BC}$ up to the mid-4th millennium BC. This gives us the opportunity to learn about the changes that took place at the end of the Mesolithic period, e.g., at the turn of the 6 th and 5 th millennium BC. Data originating from sites such as Sarurab I (Mohamed-Ali and Khabir 2003: 4I), El Qala'a and Kabbashi A (Caneva et al., 1993) and more recently 10-W-4 on the White Nile (Salvatori et al., 20II) shows that hunter/ fisher/gatherer communities still lived in Central Sudan at the end of the 6th millennium $\mathrm{BC}$, and in the Khartoum region also during first half of the 5 th millennium $\mathrm{BC}$.

In contrast to northern Sudan, where the process of Neolithization occurred earlier and probably lasted nearly 2000 years, in Central Sudan we are dealing with a rather sudden change. The question is how did this happen? Is this related to the migration of the Neolithic population to the south and eviction of Mesolithic people (Fernandez et al., 2003), and a gradual expansion along the Nile associated with climate change? But was assimilation and the adoption of a new type of economy by hunter-gatherers possible? There is also the unanswered question of why in the area of el Barga (Honneger 2004; 2005) are we seeing a hiatus spanning more than 500 years that separates Mesolithic and Neolithic settlement. Studies on oral bacterial divergence performed at the el-Khiday cemetery (Salvatori and Usai 2016: I24) showed that the Neolithic population was associated with the Mesolithic diet. On the other hand, studies of plaque showed that they consumed domesticated plants (Buckley et al., 20I4), which is confirmed by the preliminary results of research carried out by K. Hardy on Neolithic samples from Khor Shambat. This however, still does not provide us with an answer 
regarding the mechanisms of these changes. Perhaps wide-ranging strontium isotope analysis and genetic testing would help, though in the latter case, it is unlikely that DNA could be extracted from bone, as the tests done at Khor Shambat have shown.

Given how large, expansive (in terms of a new economy, ceramics, decorations, bone and stone tools, ideological changes...) and rapid this change was, we can assume that it was associated with migration. As suggested by Salvatori and Usai (2016), the Neolithization of Central Sudan was the result of a diffusion that transferred the entire Neolithic package at the same time. Yet there is still one question that we do not yet know the answer to: what happened to the Mesolithic population?

\section{ACKNOWLEDGEMENTS}

We are grateful to the National Corporation for Antiquities and Museums and the State of Khartoum for all their assistance with the organization of the excavation. This research would not be possible without the great commitment of many members of the mission in Khor Shambat, of which we wish to mention Marta Osypińska (Institute of Archaeology and Ethnology Polish Academy of Sciences), Lucy Kubiak-Martens (BIAX Consult), Aldona Kurzawska (Institute of Archaeology and Ethnology Polish Academy of Sciences), Andrzej Gałaś (AGH University of Science and Technology) Sara Abdelatif Elsheekh (National Corporation for Antiquities and Museums) and Mohammed Al Montaser Osman (Khartoum State). Finally, we thank our reviewers for their helpful comments that have improved this text.

\section{REFERENCES}

Acsádi, G. and Nemeskéri, J. 1970. History of Human Life Span and Mortality. Budapest, Akadémiai Kiadó. Ahmed, M. A. M. and Bakry, A. 2017. Prehistoric Child Burials in Sudan. Der Antike Sudan. Mitteilungen der Sudanarchäologischen Gesellschaft zu Berlin e. V28: 47-68.

Arkell, A. J. 1953. Shaheinab. An account of the excavation of a Neolithic occupation site carried out for the Sudan Antiquities Service in 1949-50. Oxford University Press.

Arriaza, B., Allison, M. and Gerszten, E. 1988. Maternal mortality in pre-Columbian Indians of Arica, Chile. American Journal of Physical Anthropology 77: 35-4I.

Bacvarov, K. 2008. A long way to the West: earliest jar burials in southeast Europe and the Near East. In K. Bacvarov (ed.), Babies Reborn: Infant/Child Burials in Pre- and Protohistory, Proceedings of WS26 at the XVth UISPP Congress in Lisbon, September 2006, 6I-70. Oxford, Archaeopress. British Archaeological Research International Series 1832.

Bar-Yosef, D. E. 2002. Egyptian-Canaanite Interaction during the fourth and third Millennia B. C.: The shell connection. In E. C. M. van den Brink and T. E. Levy (eds), Egypt and the Levant: Interrelations from the 4 th through the Early 3 rd Millennium B. C. E., I29-135. Continuum, London. 
I60 $\mid$ M. Jórdeczka, E. M. Stanaszek, P. Bobrowski, M. Chtodnicki and I. Sobkowiak-Tabaka

Bass, W. M. 1995. Human osteology: a laboratory and field manual. Missouri Archeological Society.

Bobrowski, P., Jórdeczka, M., Sobkowiak-Tabaka, I. and Binder M. 20ı6. Khor Shambat 1: New Neolithic site and cemetery in Omdurman (Sudan). Polish Archaeology in the Mediterranean 25: 447-478.

Bochenek, A. and Reicher, M. 1990. Anatomia cztowieka, t. I. Warszawa, PZWL Wydawnictwo Lekarskie.

Brickley, M., and McKinley, J. I. (eds). 2004. Guidelines to the standards for recording human remains. Institute of Field Archaeologists Paper Number 7.

Brooks, S. and Suchey, J. M. 1990. Skeletal age determination based on the os pubis: a comparison of the Acsádi-Nemeskéri and Suchey-Brooks methods. Human Evolution 5: 227-238.

Buckley, S., Usai, D., Jakob, T., Radini, A. and Hardy, K. 20I4. Dental calculus reveals unique insights into food items, cooking and plant processing in prehistoric Central Sudan. PLoS ONE 9(7): e100808. https://doi.org/10.1371/journal.pone.0100808

Buikstra, J. E. and Ubelaker, D. H. 1994. Standards for data collection from human skeletal remains. Proceedings of a seminar at the Field Museum of Natural History. Fayetteville Ark. Arkansas Archeological Survey, Research Series 44.

Caneva, I. 1988. El Geili. The history of a middle Nile environment 7000 B.C.-A.D. I500. Oxford, Archaeopress. British Archaeological Research International Series 424.

Caneva, I., Garcea, E. A. A., Gautier, A. and Van Neer, W. 1993. Prepastoral cultures along the Central Sudanese Nile. Quaternaria Nova 3: 177-252.

Chłodnicki, M. 20I8. Stratigraphy of the Kadero Neolithic cemetery. In M. Honegger (ed.), Nubian archaeology in the XXIst century. Proceedings of the XIII International Conference of Nubian Studies, Neuchatel, 1st-6th September 20I4, 215-222. Leuven-Paris-Bristol. Orientalia Lovaniensia Analecta 273.

Chłodnicki, M., Kobusiewicz, M. and Kroeper, K. (eds). 2oIr. Kadero. Poznań. Studies in African Archaeology Io.

Chłodnicki, M. and Kabaciński, J. 20I5. Radiocarbon dates from Kadero revised. In J. Kabaciński, M. Chłodnicki and M. Kobusiewicz (eds), Hunter-Garterers and Early Food Producing Societies in Northern Africa, 195-217. Poznań. Studies in African Archaeology I4.

Cruz, C. B. and Codinha S. 2010. Death of mother and child due to dystocia in 19th century Portugal. International Journal of Osteoarchaeology 20: 491-96.

Czarnetzki, A. 1972. Epigenetische Skelettmerkmale im Populationsvergleich. II. Frequezunterschiede zwichen den Geschechtern. Zeitschrift für Morphologie und Anthropologie 63: 34I-350.

Fairgrieve, S. I. and Molto, J. E. 200o. Cribra orbitalia in two temporally disjunct population samples from the Dakhleh Oasis, Egypt. American Journal of Physical Anthropology III: 319-331.

Fattovich, R. and Piperno, M. 198I. Survey of the Gash Delta - November 1980. Nyame Akuma 19: 26-30.

Fernandez, V. M., Jumeno, A. and Menéndez, M. 2003. Archaeological excavations in prehistoric sites of the Blue Nile area, Central Sudan. Complutum I4: 273-374.

Gautier, A. and Van Neer, W. 20II. The fauna of Kadero and the arrival of pastoralism in the Nile Valley of Central Sudan. In M. Chłodnicki, M. Kobusiewicz and K. Kroeper (eds), Kadero, 375-408. Poznań. Studies in African Archaeology Io.

Geus, F. 1984a. Rescuing Sudan Ancient Cultures. Khartoum.

Geus, F. 1984b. Excavations at El Kadada and the Neolithic of the Central Sudan. In L. Krzyżaniak and M. Kobusiewicz (eds), Origin and early development of food-producing cultures in North-Eastern Africa, 36I-372. Poznań, Poznan Archaeological Museum.

Gładykowska-Rzeczycka, J. J. 1976. Zmiany w układzie kostnym ludności ze średniowiecznych cmentarzysk. Badania populacji ludzkich na materiatach wspótczesnych i historycznych. Seria Antropologia 4: 85-IO2. 


\section{Neolithic Inhabitants of Khor Shambat 1, Sudan $\mid$ I6I}

Gładykowska-Rzeczycka, J. J. 1989. Schorzenia ludności prahistorycznej na ziemiach polskich. Gdańsk, Muzeum Archeologiczne w Gdańsku.

Gładykowska-Rzeczycka, J. J. 1994. Problems of estimating age and determining the profession when analyzing prehistoric skeletons. Anthropologie 32(I): 85-92.

Hamd, A. H. N. 20I2. Qalaat Shanan: a large Neolithic site in Shendi town. Sudan and Nubia I6: 8-I2.

Hamd, A. H. N. 20I5. The Late Neolithic at Qalaat Shanan site within Shendi Reach. In J. Kabaciński, M. Chłodnicki and M. Kobusiewicz (eds), Hunter-Gatherers and Early food Producing Societies in northeaster Africa, I59-176. Poznań. Studies in African Archaeology I4.

Hawke, S. C. and Wells, C. 1975. An Anglo-Saxon obstetric calamity from Kingsworthy, Hampshire. Medical and Biological Illustration 25(I): 47-5I.

Hays, T. R. 197I. The Karmakol industry: Part of the Khartoum Horizon-Style. In J. L. Shiner (ed.), The prehistory and geology of Northern Sudan. Report to National Science Foundation, 84-I53. Arlington, Va: National Science Foundation.

Hays, T. R. 1976. An examination of the Sudanese Neolithic. In B. Abebe, J. Chavaillon and J. E. G. Sutton (eds), Proceedings of the Panafrican Congress of Prehistory and Quaternary Studies, VII Session, Addis Abeba 197I, 85-92. Addis Abeba, Ministry of Culture.

Honneger, M. 2004. Settlement and cemeteries of the Mesolithic and Early Neolithic at el-Barga (Kerma region). Sudan and Nubia 8: I-6.

Honneger, M. 2005. El-Barga: un site elé pour la comprehension du Mésolithique et du début du Néolithique en Nubie. Revue de Paléobiologie 10: 95-IO4.

Jórdeczka, M., Chłodnicki, M., Sobkowiak-Tabaka, I. and Stanaszek, Ł. M. 2020. Rebirth in the afterlife: Neolithic pot burials from Khor Shambat, Sudan. AZANIA: Archaeological Research in Africa 55(I): I-25.

Kabaciński, J. 20II. Comments on radiocarbon dates. In M. Chłodnicki, M. Kobusiewicz and K. Kroeper (eds), Kadero, 4II-420. Poznań. Studies in African Archaeology Io.

Krzyżaniak, L. 1975. Kadero (first season, 1972). Etudes et Travaux 8: 36I-366.

Krzyżaniak, L. 1984. The Neolithic Habitation at Kadero (Central Sudan). In L. Krzyżaniak and M. Kobusiewicz (eds), Origin and Early Development of Food-producing Cultures in North-Eastern Africa, 309-316. Poznań.

Krzyżaniak, L. 1992. Schytek pradziejów w środkowym Sudanie. Poznań. Studies in African Archaeology 3.

Krzyżaniak, A. 20Ir. Neolithic cemetery. In M. Chłodnicki, M. Kobusiewicz and K. Kroeper (eds), Kadero, 215-266. Poznań. Studies in African Archaeology io.

Lecointe, Y. 1997. Le site néolithique d'el Ghaba: deux années d'activité (1985-1986). Archéologie du Nil Moyen 2: 69-87.

Lieverse, A. R., Bazaliiskii, V. I. and Weber, A. W. 2015. Death by twins: a remarkable case of dystocic childbirth in Early Neolithic Siberia. Antiquity 89: 23-38.

Lovejoy, C. O., Meindl, R. S, Pryzbeck, T. R. and Mensforth, R. P. 1985. Chronological metamorphosis of the auricular surface of the ilium: A new method for the determination of age at death. American Journal of Physical Anthropology 68(I): I5-28.

Malgosa, A., Alesan, A., Safont, S., Ballbé, M. and Ayala, M. M. 2004. A dystocic childbirth in the Spanish Bronze Age. International Journal of Osteoarchaeology 14: 98-103.

Malinowski, A. and Wolański, N. 1988. Metody badań w biologii cztowieka. Wybór metod antropologicznych. Warszawa, Państwowe Wydawnictwo Naukowe. 
162 M. Jórdeczka, E. M. Stanaszek, P. Bobrowski, M. Chtodnicki and I. Sobkowiak-Tabaka

Marks, A. E. and Ferring, C. R. 197I. The Karat group: An early ceramic bearing occupation of the Dongola Reach. In J. L. Shiner (ed.), The Prehistory and Geology of Northern Sudan, Report to National Science Foundation, 187-275. Arlington, Va: National Science Foundation.

Marks, A. E., Hays, T. R. and De Heinzelin, J. 1986. Preliminary report of the Southern Methodist University Expedition in the Dongola Reach. KUSH I5: 165-192.

Martin, R. and Saller, K. 1957. Lehrbuch der Anthropologie in systematischer Dartstellung. Stuttgart, Fischer.

Mohammed-Ali, A. S. and Khabir, A. M. 2003. The Wavy Line and Dotted Wavy Line pottery in the prehistory of the Central Nile and the Sahara-Sahel belt. African Archaeological Review 2O(I): 25-58.

Moreton, S. G., Rosqvist, G. C., Davies, S. J. and Bentley, M. J. 2004. Radiocarbon reservoir ages from freshwater lakes, South Georgia, Sub-Antarctic: modern analogues from particulate organic matter and surface sediments. Radiocarbon 46: 62I-626.

Nordström, H. A. 1972. Neolithic and A-Group sites. The Scandinavian Joint Expedition to Sudanese Nubia III. Stockholm, Scandinavian University Press.

Ortner, D. J. 2003. Identification of pathological conditions in human skeletal remains. San Diego, London, Elsevier.

Ortner, D. J. and Putschar, W. G. J. 1981. Identification of pathological conditions in human skeletal remains. Washington. Smithsonian Contribution to Anthropology 28.

Owsley, D. W. and Bradtmiller, B. 1983. Mortality of pregnant females in Arikara villages: osteological evidence. American Journal of Physical Anthropology 61: 33I-336.

Persson, O. and Persson, E. 1984. Anthropological report on the Mesolithic graves from Skateholm, southern Sweden. I: excavation seasons 1980-82. Lund, Institute of Archaeology, University of Lund.

Philippsen, B. 2013. The freshwater reservoir effect in radiocarbon dating. Heritage Science I: 24.

Piontek, J. 1999. Biologia populacji pradziejowych. Zarys metodyczny. Poznań, Wydawnictwo Naukowe UAM.

Pounder, D., Prokopec, M. and Pretty, G. 1983. A probable case of euthanasia amongst prehistoric Aborigines at Roonka, South Australia. Forensic Science International 23: 99-108.

Power, R. K. and Tristant, Y. 2016. From refuse to rebirth: repositioning the pot burial in the Egyptian archaeological record. Antiquity 90(354): I474-I488.

Rascón Pérez, J., Cambra-Moo, O. and González Martín, A. 2007. A multidisciplinary approach reveals an extraordinary double inhumation in the osteoarchaeological record. Journal of Taphonomy 5 : 9I-IOI.

Reinold, J. 2007. La nécropoloe néolithique d' el-Kadada au Soudan central. Les cimetières A et B (NE36-O/3-V-2 et NE-36-O/3-V-3) du kôm principal. Paris.

Rogers, J. and Waldron, T. 1995. A field guide to joint disease in archaeology. Wiley-Blackwell.

Sadig, A. M. 2008. Es-Sour: a Neolithic site near Meroe, Sudan. Antiquity Project Gallery 82(316). http:// www.antiquity.ac.uk/projgall/sadig316/

Sadig, A. M. 2012. Individuals and families: traditions of burials in the Sudanese Neolithic 5000-3000 BC. Journal of Harran University Medical Faculty 29(I): 58-93.

Sadig, A. M. 20I4. Individuals and families: traditions of burials in the Sudanese Neolithic 5000-3000 BC (Correction and update). ADAB. Journal of Faculty of Arts. University of Khartoum 32: II5-II8.

Salvatori, S. 2012. Disclosing archaeological complexity of the Khartoum Mesolithic: New data at the site and regional level. African Archaeological Review 29: 399-472.

Salvatori, S., Usai, D. and Zerboni, A. 2orr. Mesolithic site formation and palaeoenvironment along the White Nile (Central Sudan). African Archaeological Review 28: 177-2II. 
Salvatori, S. and Usai, D. 20I6. Ghaba in Context. In S. Salvatori, D. Usai, and Y. Lecointe (eds), Ghaba. An early Neolithic cemetery in Central Sudan. Vol. I, I2I-I47. Frankfurt, Germany.

Salvatori, S., Usai, D. and Lecointe, Y. (eds). 2016. Ghaba. An early Neolithic cemetery in Central Sudan. Vol. I. Frankfurt, Germany.

Shiner, J. L. 1968a. The Khartoum variant industry. In F. Wendorf (ed.), The Prehistory of Nubia, 768-790. Dallas, Texas, Southern Methodist University Press.

Shiner, J. L. 1968b. The cataract tradition. In F. Wendorf (ed.), The Prehistory of Nubia, 535-629. Dallas, Texas, Southern Methodist University Press.

Shiner, J. L. (ed.) I97I. The prehistory and geology of northern Sudan, Report to National Science Foundation. Arlington, Va: National Science Foundation.

Smith-Guzmán, N. E. 20I5. Cribra orbitalia in the ancient Nile Valley and its connection to malaria. International Journal of Paleopathology IO: I-I2.

Stein, M., Lazar, B. and Goldstein, S. L. 20I3. Radiocarbon reservoir ages as freshwater-brine monitors in Lake Lisan, Dead Sea system. Radiocarbon 55: I050-1057.

Streit, K. 20I6. Protohistoric infant jar burials of the Southern Levant in context: Tracing cultural influences in the late sixth and fifth Millennia BCE. In S. Ganor, I. Kreimerman, K. Streit and M. Mumcuoglu (eds), From Sha'ar Hagolan to Shaaraim. Essays in honour of Prof. Yosef Garfinkel, 171-I86. Jerusalem, Israel Exploration Society.

Strzałko, J., Piontek, J. and Malinowski, A. 1972. Problem rekonstrukcji wzrostu na podstawie kości zachowanych we fragmentach lub spalonych. Przeglad Antropologiczny 38(2): 277-287.

Strzałko, J. and Henneberg, M. 1975. Określanie płci na podstawie morfologii szkieletu. Przeglad Antropologiczny 4I(I): 105-I26.

Stuart-Macadam, P. 1991. Anaemia in Roman Britain. In H. Bush and M. Zvelebil (eds), Health in past societies: Biocultural interpretations of human skeletal remains in archaeological contexts, IOI-II3. Oxford. British Archaeological Reports International Series 567.

Trotter, M. and Gleser, G. C. 1952. Estimation of stature from long bones of American Whites and Negroes. American Journal of Physical Anthropology 10: 463-514.

Ubelaker, D. H. 1978. Human skeletal remains. Excavation, analysis, interpretation. Chicago.

Van den Brink, E. C. M., Horwitz, L. K., Kool, R., Liphschitz, N., Mienis, H. K. and Zbenovich, V. 2015. Excavations at Tel Lod: Remains from the Pottery Neolithic A, Chalcolithic, Early Bronze Age I, Middle Bronze Age I and Byzantine Periods. Atiqot 82: I4I-2I8.

Wapler, U., Crubézy, E. and Schultz, M. 2004. Is cribra orbitalia synonymous with anemia? Analysis and interpretation of cranial pathology in Sudan. American Journal of Physical Anthropology 123(4): 333-339.

Wells, C. 1978. A medieval burial of a pregnant woman. The Practitioner 221: 442-444.

White, T. D. and Folkens, P. A. 2005. The human bone manual. San Diego, Academic Press.

Willis, A. and Oxenham, M. F. 20I3. A case of maternal and perinatal death in Neolithic southern Vietnam, c. 2100-1050 BCE. International Journal of Osteoarchaeology 23: 676-684.

Zarifa G., Sholts, S. B., Tichinin, A., Rudovica, V., Vīksna, A., Engīzere, A., Muižnieks, V., Bartelink, E. J. and Wärmländer, S. K. T. S. 20I6. Cribra orbitalia as a potential indicator of childhood stress: Evidence from paleopathology, stable $\mathrm{C}, \mathrm{N}$, and $\mathrm{O}$ isotopes, and trace element concentrations in children from a I7th-18th century cemetery in Jēkabpils, Latvia. Journal of Trace Elements in Medicine and Biology 38: I3I-I37. 
